Article

\title{
Integration of In Situ and Remote Sensing Measurements for the Management of Harmful Cyanobacteria Blooms. A Lesson from a Strategic Multiple-Uses Reservoir (Lake Occhito, South Italy)
}

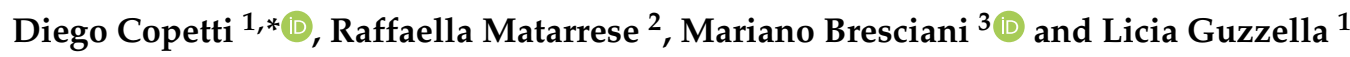 \\ 1 Water Research Institute, National Research Council of Italy, IRSA-CNR, Section of Brugherio, \\ Via del Mulino 19, 20861 Brugherio, MB, Italy; guzzella@irsa.cnr.it \\ 2 Water Research Institute, National Research Council of Italy, IRSA-CNR, Section of Bari, Via De Blasio 5, \\ 70132 Bari, BA, Italy; raffaella.matarrese@ba.irsa.cnr.it \\ 3 Institute for Electromagnetic Sensing of the Environment, National Research Council of Italy, IREA-CNR, \\ Section of Milano, Via Bassini 15, 20133 Milan, MI, Italy; bresciani.m@irea.cnr.it \\ * Correspondence: copetti@irsa.cnr.it; Tel.: +39-039-21693215
}

check for updates

Citation: Copetti, D.; Matarrese, R.; Bresciani, M.; Guzzella, L. Integration of In Situ and Remote Sensing

Measurements for the Management of Harmful Cyanobacteria Blooms. A Lesson from a Strategic Multiple-Uses Reservoir (Lake Occhito, South Italy). Water 2021, 13, 2162. https: / / doi.org/10.3390/w13162162

Academic Editor: Kun Shi

Received: 21 June 2021

Accepted: 3 August 2021

Published: 6 August 2021

Publisher's Note: MDPI stays neutral with regard to jurisdictional claims in published maps and institutional affiliations.

Copyright: (c) 2021 by the authors. Licensee MDPI, Basel, Switzerland. This article is an open access article distributed under the terms and conditions of the Creative Commons Attribution (CC BY) license (https:/ / creativecommons.org/licenses/by/ $4.0 /)$.

\begin{abstract}
Harmful cyanobacteria blooms (HCBs) are one of the main water quality threats affecting reservoirs. Guidelines suggest integrating laboratory, real-time in situ, and remote sensing data in the monitoring of HCBs. However, this approach is still little adopted in institutional measuring programs. We demonstrated that this integration improves frequency and spatial resolution of the data collection. Data were from an intense HCB (Planktothrix rubescens), which occurred in a south Italy multiple-uses reservoir (Lake Occhito) between 2008 and 2009 and regarded both the lake and the irrigation network. Laboratory and in situ fluorometric data were related to satellite imagery, using simple linear regression models, to produce surface lake-wide maps reporting the distribution of both $P$. rubescens and microcystins. In the first node of the distribution network, microcystin concentrations $\left(4-10 \mu \mathrm{g} \mathrm{L}^{-1}\right)$ reached values potentially able to damage the culture and to accumulate during cultivation. Nevertheless, our study shows a decrease in the microcystin content with the distance from the lake $\left(0.05 \mu \mathrm{g} \mathrm{L}^{-1} \mathrm{~km}^{-1}\right)$, with a reduction of about $80 \%$ of the microcystin concentrations at the furthest tanks. Recent improvements in the spatial resolution (i.e., tens of meters) of satellite imagery allow us to monitor the main tanks of large and complex irrigation systems.
\end{abstract}

Keywords: harmful cyanobacteria blooms; microcystins; multiple-uses reservoirs; irrigation network; in situ measurements; remote sensing

\section{Introduction}

Cyanobacterial blooms are becoming increasingly frequent in lakes [1-3]; their increase is likely driven by different factors related to both global (e.g., atmospheric temperature increase) and local (e.g., nutrient loads) environmental modifications [4-7]. Mass development of cyanobacteria may determine different detrimental effects on the lake ecosystem, including a turbidity increase and oxygen depletion, with negative effects for macrophytes, invertebrates, and fish species [8]. Although cyanobacteria are a natural component of the planktonic population [9], some cyanobacterial species can produce toxic peptides and alkaloids [10], whose presence can determine a reduction in the ecosystem services, such as drinking and irrigational supply, fishing, and bathing [3,11-13]. Management of cyanobacteria blooms is thus of fundamental importance to protect both lake ecosystems and human health [3].

In recent decades, the filamentous and potentially toxic cyanobacterium Planktothrix rubescens has colonized many environments in Europe [14], often appearing in mesotrophic 
conditions during the recovery of the trophic state of the lakes [15-17]). P. rubescens is a red-colored species, also known as 'Burgundy blood alga', because its presence can cause an intense redness of the lake waters $[9,18]$. A conspicuous presence of this species has also been recently documented in Italy [19] with examples in northern [14,20,21], central [22,23], and southern [24,25] Italy.

P. rubescens presents some very specific eco-physiological traits [9,26]. It can slowly regulate its position over the water column through the production of gas vesicles [27], and it is well adapted to grow at very low levels of incident radiation $[9,28]$. These features have important implications for its phenology [15]. During winter maximum overturn, the filaments of this species are spread over the entire water column; then, with the incipient spring stratification, they tend to move deeper to protect their cells from the increased incident solar radiation [29]. In summer, with the sharpening of the thermal gradient and the lowering of the thermocline, P. rubescens cells tend to sink further and to form plate-like layers in the stable metalimnion [30]. Here, they find the best compromise between incident solar radiation and nutrient availability, which allows them to overcome the critical summer period [9]. In autumn, with the extending of the vertical mixing, $P$. rubescens filaments are spread again over an increasingly larger volume of the water column [14]. In these conditions, the cells of this species can intercept the augmented nutrient availability (potentially from both external sources and internal recycle) and bloom [15,31]. The more intense the autumnal bloom, the higher the winter inoculum will be, which in turn is essential for the success of this species in the subsequent growing season [21].

In terms of cyanotoxins, $P$. rubescens produces microcystins, metabolites with hepatotoxic effects [32-35] suspected to be tumor promoters [25]. Compared to other species, P. rubescens is characterized by a relatively simple toxin profile consisting of two to four demethyl variants of microcystin-RR: [D-Asp3, Dhb7] MC-RR, [D-Asp3] MC-RR, or [Dha7] MC-RR [32].

The cyanotoxin production in cyanobacteria population depends on different factors, including the percentage of genotypes able to produce cyanotoxins, the availability of light and nutrients, and the population growth stage [10]. Different studies found a significant correlation between microcystin endo-cellular concentration and cell density of $P$. rubescens $[32,34,36,37]$. Briand et al. [32] reported a microcystin cellular quota (the content of microcystin per cell or unit of biomass) in natural conditions in a range of 0.1-0.3 pg cell $\mathrm{L}^{-1}$. Salmaso et al. [34] compared the microcystin production in four Italian lakes (including Lake Occhito) and demonstrated the existence of a clear lake-specific relationship linking the intracellular microcystin concentration and the P. rubescens' biomass. The microcystin cell quota in Lake Occhito resulted about fivefold higher compared to the other three case studies (i.e., Lake Ledro, Pusiano, and Garda) with a microcystin quota of $3.16 \mu \mathrm{g} \mathrm{mm}^{-3}$ corresponding to $0.26 \mathrm{pg}$ cell ${ }^{-1}$.

The correct management of cyanobacteria blooms needs the availability of high-quality data collected with an adequate temporal and spatial detail [11]. In recent decades, remote sensing techniques have been emerging as a powerful tool to furnish high spatial and temporal resolution data on algal blooms $[6,38]$. Since the first studies carried out in late 1970 [39], many algorithms have been implemented to monitor the algal population via remote sensing. Some of them are simply based on a spectral band ratio; others (i.e., semi-analytic or analytic) require more auxiliary information $[40,41]$ and are characterized by a higher level of complexity. Cyanobacteria are generally monitored via remote sensing using the biomarker pigment phycocyanin ([42-44]. Phycocyanin is a secondary accessory pigment belonging to the family of the phycobiliprotein present in all the cyanobacteria species, which is used to increase the light harvesting in the visible spectrum [9]. The presence of phycocyanin (absorption maxima $\sim 615-640 \mathrm{~nm}$, [45]), gives a specific pattern to the reflectance spectrum. A maximum reflectance, near $650 \mathrm{~nm}$, has been used to monitor cyanobacteria $[40,46]$. In addition to phycocyanin, P. rubescens cells contain phycoerythrin, the phycobiliprotein responsible for the intense reddish coloring of its blooms $[47,48]$. This 
pigment absorbs strongly at around $590 \mathrm{~nm}$ and gives a strong signal in reflectance between $680 \mathrm{~nm}$ and $709 \mathrm{~nm}$ [49]. The backscattering/absorption that creates a peak around $709 \mathrm{~nm}$ is highly correlated [50,51] with algae and cyanobacterial biomass at higher trophic states (Chl-a $>20 \mathrm{mg} \mathrm{m}^{-3}$ ), and this portion of the spectrum in remote sensing applications is used to generate quantitative maps of cyanobacteria bloom [52-54].

In this paper we present the results of a study conducted between April 2009 and April 2010 in a strategic multiple-uses (irrigation and drinking supply) reservoir (Lake Occhito) located in South Italy, affected by a strong P. rubescens bloom. In situ measurements regarded both the lake ecosystem and the irrigation network, which is fed by the lake waters during the agricultural season. The distribution of the P. rubescens bloom on the lake surface was also monitored via remote sensing. The algorithm developed in this study uses signal bands in the regions of $\sim 680-710 \mathrm{~nm}$, associated with phycoerythrin. Lake-wide maps of the $P$. rubescens surface distribution were developed and their usefulness and limitations for the management of cyanobacteria blooms are discussed. This paper also reports the trend of $P$. rubescens contamination in a large and complex irrigation network during the bloom, discussing how real-time in situ and remote sensing monitoring could improve the water withdrawal and the management of the bloom spread in the irrigation system, respectively.

\section{Materials and Methods}

\subsection{Study Site}

Lake Occhito $\left(41^{\circ} 34^{\prime} 48^{\prime \prime} \mathrm{N}, 14^{\circ} 56^{\prime} 42^{\prime \prime} \mathrm{E}\right)$ is one of the largest Italian reservoirs. It has a maximum surface area and a total volume of about $14 \mathrm{~km}^{2}$ and $333 \times 10^{6} \mathrm{~m}^{3}$, respectively (Table 1).

Table 1. Morphometric features of Lake Occhito.

\begin{tabular}{ccc}
\hline Variable & Value & Unit \\
\hline Watershed area & 1012 & $\mathrm{~km}^{2}$ \\
Lake area & 13.74 & $\mathrm{~km}^{2}$ \\
Maximum elevation & 198 & $\mathrm{~m} \mathrm{a.s.l.}$ \\
Maximum depth & 40 & $\mathrm{~m}$ \\
Maximum width & 2000 & $\mathrm{~km}$ \\
Lake volume & $333 \times 10^{6}$ & $\mathrm{~m}^{3}$ \\
Irrigation network area & 600 & $\mathrm{~km}^{2}$ \\
\hline
\end{tabular}

The dam is built on the bed of the Fortore River (Figure 1); the reservoir watershed $\left(\sim 1000 \mathrm{~km}^{2}\right)$ drains the waters of several stream inflows (Figure 1). The lake water is used as a drinking supply $\left(600 \times 10^{3}\right.$ inhabitants $)$ and for the irrigation of the Tavoliere di Puglia, a strategic agricultural area in South Italy. The dam has a height of about $40 \mathrm{~m}$; water withdrawal occurs from an opening $12 \mathrm{~m}$ wide and $8 \mathrm{~m}$ high, located at a fixed height of $11.5 \mathrm{~m}$ above the lake bottom. After withdrawal, the water enters a tunnel and reaches the Finocchito splitter from which it is distributed by gravity to the proper irrigation network and to the drinking treatment plant, respectively. Drinking water is furnished continuously with an average flow rate of about $1 \mathrm{~m}^{3} \mathrm{~s}^{-1}$. Maximum water withdrawal is due to irrigation between April and October $\left(25 \mathrm{~m}^{3} \mathrm{~s}^{-1}\right)$. The irrigation network is fed solely by the Lake Occhito waters and consists of several storage tanks serving a total area of about $600 \mathrm{~km}^{2}$ (Figure 1). 


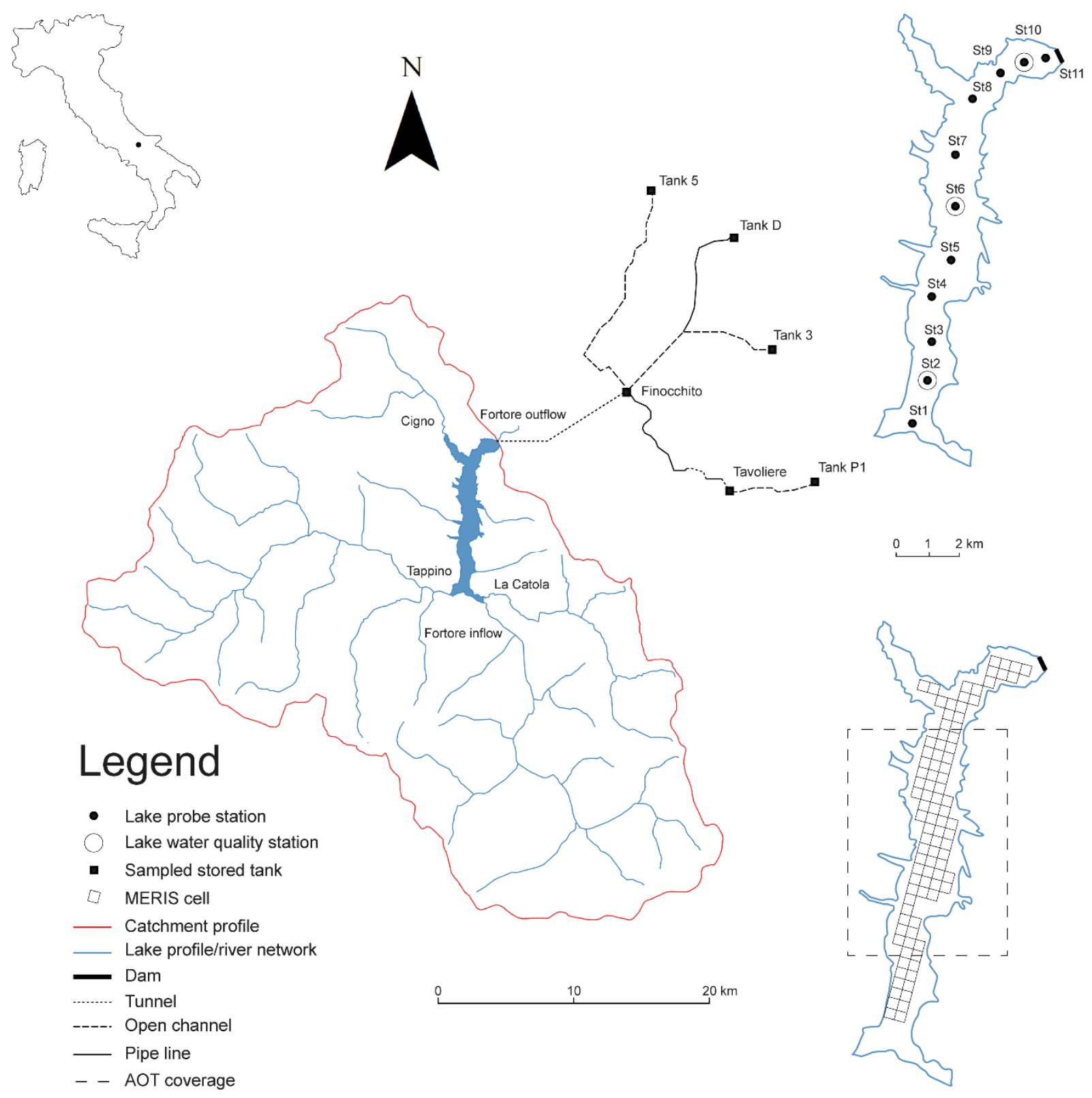

Figure 1. Top left: Lake Occhito position in the Italian peninsula. Main panel: Lake Occhito profile within its catchment and a schematic of the main rivers and of the irrigation network, including the storage tanks sampled in this study. Top right: Lake Occhito profile with indication of the in-situ sampling stations. Bottom right: Lake Occhito profile containing the MERIS (Medium Resolution Imaging Spectrometer) cell coverage used in this study. The dashed line delimits the area where the MOD09 AOT (Aerosol Optical Thickness) values were averaged to be used for the atmospheric corrections of MERIS data.

An extraordinary P. rubescens bloom occurred in Lake Occhito in late winter 2008 [37]. An emergency monitoring program, focused on the impact of the bloom on the drinking water supply, was undertaken by the Regional Agency for Environmental Prevention from January 2009 [37]. Data from this monitoring program describe the bloom evolution from January to July 2009 with the highest values of both P. rubescens cell density $\left(140-160 \times 10^{6}\right.$ cell L $\left.{ }^{-1}\right)$ and microcystin concentrations $\left(31 \mu \mathrm{g} \mathrm{L}^{-1}\right)$ detected between March and April 2009. In the two following years (2010-2011), both cell densities $\left(<30 \times 10^{6}\right.$ cell $\left.\mathrm{L}^{-1}\right)$ and microcystin concentrations $\left(<2 \mu \mathrm{g} \mathrm{L}{ }^{-1}\right)$ were well below the values monitored during the 2008-2009 bloom [55]. 
The field campaigns presented in this paper were carried out in the period of April 2009-April 2010 and were addressed to the detection of the P. rubescens bloom distribution in the lake and on its spread in the irrigation network that was monitored only within this study.

\subsection{In Situ Measurements}

\subsubsection{Sampling Stations}

Lake Occhito was sampled along the main south-north transect (Figure 1) following the lake talweg in four field campaigns conducted on 6 April, 23 June, 19 October 2009, and 14 April 2010. During the first field campaign the water was withdrawn with a flow rate of 2-3 $\mathrm{m}^{3} \mathrm{~s}^{-1}$, while in the remaining with a normal discharge of about $25 \mathrm{~m}^{3} \mathrm{~s}^{-1}$. The main lake transect (south-north) was sampled in 11 stations from the southernmost region of the lake (St1) to the dam (St11). All the stations were profiled from the surface to the bottom using both a multiparametric and a fluorometric probe. Discrete water samples for chemical analysis (i.e., hydrochemical variables and microcystins) and phytoplankton counting were collected in selected stations (St2, St6, and St10) and at different depths using a Niskin bottle (Figure 1). Samples for microcystin analysis were collected at the chlorophyll-a maximum.

Six relevant tanks were sampled in the irrigation network: Finocchito, Tavoliere, Tank D, Tank 5, Tank P1, and Tank 3 (Figure 1). Superficial samples were taken from the shore of each tank. The distance between the lake and these tanks (Table S1) is between 16 (Finocchito) and 51 (Tank 5) km, and the surface area ranges from 100 (Tank P1) to $2.4 \times 10^{4} \mathrm{~m}^{2}$ (Tank 3). The Finocchito splitter was sampled for both phytoplankton counting and microcystin concentrations at 11 sampling dates between April 2009 and April 2010. All the six tanks were sampled for microcystin concentrations at 6 sampling dates (synoptic campaign) between June and November 2009.

\subsubsection{Field Equipment and Laboratory Methods}

Temperature, conductivity, $\mathrm{pH}$, dissolved oxygen (DO), turbidity and Photosynthetically Available Radiation (PAR) profiles were performed with a vertical resolution of $0.1 \mathrm{~m}$ using the multiparametric probe Idronaut Ocean seven 316 Plus (http:/ / www.idronaut.it/) (accessed on 4 August 2021).

Chlorophyll-a profiles were undertaken using bbe-FluoroProbe (http:/ / www.bbemoldaenke.de) (accessed on 4 August 2021) at a vertical resolution of about $0.5 \mathrm{~m}$. FluoroProbe allows measuring total chlorophyll-a (T-chl-a) concentrations and the relative contribution of four spectral classes [56]. In the present study, we measured the chlorophylla content of the following classes: P. rubescens (P-chl-a), diatoms (D-chl-a), cryptophyta (Cr-chl-a) and chlorophytes (Ch-chl-a). P-chl-a concentrations were measured using a specific spectral fingerprint [56] determined from P. rubescens natural strains collected on Lake Occhito before the commencement of the field campaigns (see Carraro et al. [29] for the adopted method). The chlorophyll-a content of the other three classes was measured using the fingerprint provided by the manufacture. The relationship between biovolume and chlorophyll-a concentrations for the different groups are reported in Figure S1 (see also Text S1).

Total nitrogen (TN), total phosphorous (TP), and dissolved reactive phosphorus (DRP) were measured using the methods reported in Valderrama [57,58]. The limit of quantification (LOQ) for the phosphorus species was $2 \mu \mathrm{g} \mathrm{P} \mathrm{L}{ }^{-1}$. Ammonium $\left(\mathrm{N}-\mathrm{NH}_{4}\right)$, silica $\left(\mathrm{SiO}_{2}\right)$ and main hydrochemical variables were measured using the methods reported in APHA et al. $[59,60]$ Total inorganic nitrogen (TIN) was estimated as the sum of ammonium $\left(\mathrm{N}-\mathrm{NH}_{4}\right)$ and nitrate $\left(\mathrm{N}-\mathrm{NO}_{3}\right)$.

Phytoplankton samples were fixed directly in the field with Lugol's solution. Specific identification and biovolume estimation were carried out following the methods reported in Legnani et al. [31]. 
Microcystin concentrations were detected distinguishing between the microcystin content in the P. rubescens cells (intracellular microcystins, I-mc) and the microcystin dissolved in the water (extracellular microcystins, E-mc) following the methods reported in Salmaso et al. [34] and Guzzella et al. [61] LOQ was 0.1 and $0.3 \mu \mathrm{g} \mathrm{L}^{-1}$ for I-mc and E-mc, respectively. Total microcystin (T-mc) concentrations were calculated as the sum of intracellular and external microcystin concentrations.

\subsection{Satellite Data}

Satellite imagery used in this study was acquired from MERIS (Medium Resolution Imaging Spectrometer) and MODIS (Moderate Resolution Imaging Spectrometer) sensors. MERIS (http:/ / envisat.esa.int) (accessed on 4 August 2021) was a $68.5^{\circ}$ field-of-view pushbroom imaging spectrometer active from 2004 to 2012, providing a global coverage every 3 days. MERIS provided measures of the solar radiation reflected by the Earth at a ground spatial resolution of $300 \mathrm{~m}$ in 15 programmable spectral bands between 390 and $1040 \mathrm{~nm}$. Its primary objective was to allow quantitative observations of marine constituents such as chlorophyll-a, total suspended solid, and colored dissolved organic matter [62]. MODIS (http:/ / modis.gsfc.nasa.gov/) (accessed on 4 August 2021) is a key instrument aboard the TERRA (EOS AM) and AQUA (EOS PM) satellites. TERRA's orbit around the Earth is timed so that it passes from north to south across the equator in the morning, while AQUA passes from south to north through the equator in the afternoon. This allows TERRA and AQUA MODIS to view the entire Earth's surface every 1 or 2 days, acquiring data in 36 spectral bands, or groups of wavelengths, with $1 \mathrm{~km}$ spatial resolution.

Based on the results of our monitoring activity and on the data reported in Assennato et al. $[37,55]$, we analyzed MERIS and MODIS images in the period of October 2008-October 2009, which includes the whole period of the bloom evolution. For this period, we selected 6 days with both a MERIS image and the corresponding MODIS surface reflectance product (MOD09). A total of 176 MERIS cells overlapped the lake surface; from these cells, we removed those partially falling on the ground, obtaining a maximum of 95 completely wet cells that were used in this study (Figure 1). In addition to the surface reflectance of the Lake Occhito waters, the MOD09 product provided the TOA (Top Of Atmosphere reflectance) coverage at $1 \mathrm{~km}$ spatial resolution. The AOT (Aerosol Optical Thickness) at $555 \mathrm{~nm}$ computed by MOD09 was averaged over the lake surface (Figure 1, dashed rectangle) and then used to atmospherically correct MERIS data by means of the SMAC (Simplified Method for Atmospheric Corrections) processor available within the VISAT-BEAM (http:/ / www.brockmann-consult.de/cms/web/beam/) (accessed on 4 August 2021) tool. SMAC is a semi-empirical approximation of the radiative transfer in the atmosphere that considers two-way gaseous transmission, atmospheric spherical albedo, total atmospheric transmission, Rayleigh scattering, and aerosol scattering [63].

An index based on the MERIS water leaving reflectance (WLR) at Band $8(681 \mathrm{~nm})$ and Band $9(708 \mathrm{~nm})$ after atmospheric correction was then established and used to develop a linear regression model with P-chl-a data collected in 15 stations over the south-north transect (S1-S11) on 6 Apr 2009 and 23 Jun 2009 field campaigns (see results section). P-chl-a values were mediated over the first $5 \mathrm{~m}$ of the water column. The model was then used to reconstruct the bloom development.

\subsection{Data Analysis and Calculations}

The R software (https:/www.rproject.org) (accessed on 4 August 2021) was employed to perform linear regression analysis (Ordinary Least Squares, OLS). QQ plots were used to visually check the distribution of the standardized residuals. The following diagnostic tests ("lmtest" library) were then carried out on the residuals: $t$ Student (zero mean condition), Shapiro-Wilk (normal distribution), Breusch-Pagan (homoscedasticity), Durbin-Watson (serial independence), adopting a $0.05 p$-value threshold of acceptance [64]. Confidence intervals at $95 \%$ were estimated using the "predict" function of the "Imtest" library. Errors 
between modelled and observed data were estimated through root mean square error (RMSE) using the formula in Equation (1) [65]:

$$
R M S E=\sqrt{\frac{\sum_{i=1}^{N}\left(M_{i}-O_{i}\right)^{2}}{N}}
$$

where $N$ is the number of observations, $O_{i}$ and $M_{i}$ are the "ith" observed and model data.

The limit of the euphotic zone was calculated as $1 \%$ of the incident solar radiation (Lee et al., 2007).

Phytoplankton biodiversity was calculated from biovolume data, using the ShannonWiener (log 10) index [66,67].

Figure 1 was carried out using QGIS. Plots were obtained through Microsoft Excel and Matlab software. Matlab was used to perform P-chl-a-depth-length interpolations (i.e., contourf command) presented in Figure 3. Graphic representations were finally assembled using Adobe Illustrator.

\section{Results}

\subsection{Lake In Situ Measurements}

In the four field campaigns, a total of 35 phytoplankton species were identified and divided into seven taxonomic groups: Bacillariophyceae, Chlorophyceae, Chrysophyceae, Cyanobacteria, Coniugate, Cryptophyceae, and Dinophyceae (Table S2). Apart from the April 2010 field campaign, the phytoplankton assemblage was always dominated by $P$. rubescens (Table 2 ). In addition to $P$. rubescens, 11 species contributed significantly ( $>5 \%$ in a sample) to the total biovolume (Table S2). The diversification of the algal population was therefore rather limited, as indicated by the relatively low values of the median Shannon index (Table 2) between 0.1 and 1.2 (highest values detected in October 2009).

Table 2. Statistics of the main phytoplankton descriptors related to station St6 in the four field campaigns, reporting minimum (italic), median (bold), and maximum (normal) values. T-bv = total biovolume $\left(\mathrm{mm}^{3} \mathrm{~m}^{-3}\right) ; \mathrm{P}-\%=$ percentage of P. rubescens to the total biovolume $(\%) ; \mathrm{P}-\mathrm{cd}=$ P. rubescens cell density $\left(10^{6}\right.$ cell L $\left.{ }^{-1}\right)$; $\mathrm{SI}=$ Shannon index. 6 April 2009: $\mathrm{N}=6, \mathrm{Dr}=0.5-15 ; 23$ June 2009: $\mathrm{N}=5$, Dr = 0.5-20; 19 October 2009: $\mathrm{N}=4$, Dr = 0.5-20; 14 April 2010: $\mathrm{N}=3, \mathrm{Dr}=0.5-20 . \mathrm{N}=$ number of samples; $\mathrm{Dr}=$ depth range $(\mathrm{m})$.

\begin{tabular}{ccccc}
\hline & T-bv & P-\% & P-cd & Sh \\
\hline \multirow{3}{*}{ 6 April 2009 } & 3106 & 67 & 26 & 0.4 \\
& 6894 & 90 & 77 & 0.5 \\
\multirow{3}{*}{ 23 June 2009 } & 8589 & 90 & 95 & 1.0 \\
& 1122 & 46 & 14 & 0.1 \\
\multirow{3}{*}{ 19 October 2009 } & 1395 & 97 & 15 & 0.2 \\
& 2837 & 100 & 34 & 1.3 \\
& 32 & 44 & 0.2 & 0.7 \\
14 April 2010 & 73 & 70 & 0.6 & 1.2 \\
& 88 & 10 & 0.8 & 0.9 \\
& 204 & 21 & 0.5 & 1.0 \\
\hline
\end{tabular}

Maximum total phytoplankton biovolume (T-bv) was measured in April 2009 (median $6894 \mathrm{~mm}^{3} \mathrm{~m}^{-3}$ ) when the median contribution of P. rubescens (P-\%) to the total biovolume was $90 \%$ with a P. rubescens cell density (P-cd) of $77 \times 10^{6}$ cell L $^{-1}$ (Table 2$)$. In June, the average biovolume decreased to about $20 \%$ of that of April (median $1395 \mathrm{~mm}^{3} \mathrm{~m}^{-3}$ ), with the $P$. rubescens contribution at $97 \%$ and the average $P$. rubescens cell density of $15 \times 10^{-6}$ cell $\mathrm{L}^{-1}$. In October, the total biovolume decreased again by about two orders of magnitude (median $73 \mathrm{~mm}^{3} \mathrm{~m}^{-3}$ ) with a concomitant reduction in the P. rubescens 
cell density (median $0.6 \times 10^{6}$ cell L $\left.{ }^{-1}\right)$; that, however, maintained a relatively high contribution to the total biovolume (median 70\%). In April 2010, total biovolume increased slightly (median $406 \mathrm{~mm}^{3} \mathrm{~m}^{-3}$ ) compared to October, but it remained considerably lower than that detected in spring and summer 2009. In April 2010, furthermore, an abrupt shift in dominance occurred, with a marked decrease in the P. rubescens median contribution to the total biovolume $\left(21 \%\right.$, median cell density $\left.0.5 \times 10^{6} \mathrm{cell} \mathrm{L}^{-1}\right)$ in favor of Fragillaria acus (Bacillariophycea) that covered about $70 \%$ of the total biovolume (not shown).

In April 2009, the lake water column was weakly stratified with a vertical gradient (Table 3) of about $6{ }^{\circ} \mathrm{C}$ between the lake surface and the lake bottom (see also Figure 2). This gradient increased to $12.6^{\circ} \mathrm{C}$ in June and then decreased again to $5.5^{\circ} \mathrm{C}$ in October, underlining an advanced process of destratification in fall. In spring 2010, the stratification of the water column was less pronounced in comparison to the previous year, with temperature differences of only $3.2^{\circ} \mathrm{C}$.

Table 3. Statistics of the relevant limnological variables collected at station St6 during the four field campaigns reporting minimum (italic), median (bold), and maximum (normal) values. Temp $=$ temperature $\left({ }^{\circ} \mathrm{C}\right)$, Cond = electrical conductivity $\left(\mu \mathrm{S} \mathrm{cm}^{-1} 20^{\circ} \mathrm{C}\right), \mathrm{DO}=$ dissolved oxygen $\left(\mathrm{mg} \mathrm{L}^{-1}\right), \mathrm{T}-\mathrm{chl}-\mathrm{a}=$ total chlorophyll-a $\left(\mu \mathrm{g} \mathrm{L}^{-1}\right), \mathrm{N}-\mathrm{NH}_{4}=\operatorname{ammonium}\left(\mu \mathrm{g} \mathrm{N} \mathrm{L}^{-1}\right)$, $\mathrm{N}-\mathrm{NO}_{3}=$ nitrate $\left(\mathrm{mg} \mathrm{N} \mathrm{L}^{-1}\right), \mathrm{TN}=$ total nitrogen $\left(\mathrm{mg} \mathrm{N} \mathrm{L}^{-1}\right), \mathrm{DRP}=$ dissolved reactive phosphorus $\left(\mu \mathrm{g} \mathrm{P} \mathrm{L}^{-1}\right), \mathrm{TP}^{-}$total phosphorus ( $\left.\mu \mathrm{g} \mathrm{P} \mathrm{L}^{-1}\right), \mathrm{SiO}_{2}=$ silica $\left(\mathrm{mg} \mathrm{L}^{-1}\right) .6$ April 2009: $\mathrm{N}=5, \mathrm{Dr}=0.5-30 \mathrm{~m} ; 23$ June 2009: $\mathrm{N}=6, \mathrm{Dr}=0.5-30 \mathrm{~m} ; 19$ October 2010: $\mathrm{N}=6, \mathrm{Dr}=0.5-20 \mathrm{~m} ; 14$ April 2010: $\mathrm{N}=8, \mathrm{Dr}=0.5-25 \mathrm{~m} . \mathrm{N}=$ number of samples, $\mathrm{Dr}=$ depth range.

\begin{tabular}{|c|c|c|c|c|c|c|c|c|c|c|c|c|}
\hline Date & Temp & Cond & T-chl-a & DO & TP & DRP & TN & TIN & $\mathrm{N}-\mathrm{NO}_{3}$ & $\mathrm{~N}-\mathrm{NH}_{4}$ & TN/TP & $\mathrm{SiO}_{2}$ \\
\hline & 8.4 & 588 & 11 & 9.9 & 26 & 1 & 2.3 & 1.6 & 1.6 & 16 & 84 & 4.6 \\
\hline \multirow[t]{3}{*}{6 April 2009} & 9.6 & 610 & 19 & 11.2 & 30 & 2 & 2.3 & 1.8 & 1.8 & 18 & 173 & 4.7 \\
\hline & 14.6 & 611 & 41 & 12.4 & 64 & 2 & 2.5 & 1.9 & 1.8 & 34 & 202 & 4.8 \\
\hline & 10.8 & 488 & 5 & 3.5 & 17 & 4 & 1.0 & 0.6 & 0.5 & 16 & 127 & 4.0 \\
\hline \multirow[t]{3}{*}{23 June 2009} & 16.8 & 565 & 9 & 9.1 & 21 & 4 & 1.7 & 1.2 & 1.0 & 138 & 152 & 4.5 \\
\hline & 23.4 & 589 & 18 & 9.5 & 27 & 5 & 2.2 & 1.7 & 1.2 & 450 & 217 & 4.6 \\
\hline & 12.1 & 510 & 1 & 1.8 & 8 & 3 & 0.8 & 0.4 & 0.0 & 86 & 128 & 3.0 \\
\hline \multirow[t]{3}{*}{19 October 2009} & 17.5 & 511 & 1 & 7.5 & 10 & 5 & 0.8 & 0.4 & 0.3 & 90 & 172 & 3.0 \\
\hline & 17.6 & 575 & 1 & 8.0 & 14 & 19 & 1.6 & 0.9 & 0.4 & 858 & 203 & 4.7 \\
\hline & 9.0 & 518 & 3 & 9.7 & 16 & 3 & 1.5 & 1.2 & 1.2 & 12 & 127 & 3.8 \\
\hline \multirow[t]{2}{*}{14 April 2010} & 11.7 & 551 & 4 & 11.4 & 18 & 5 & 1.6 & 1.3 & 1.2 & 22 & 199 & 3.8 \\
\hline & 12.3 & 583 & 10 & 11.9 & 27 & 10 & 1.7 & 1.6 & 1.6 & 71 & 214 & 3.9 \\
\hline
\end{tabular}

T-chl-a concentrations reflected the trend of the total phytoplankton biovolume and showed the highest values in April 2009 (Table 3). A similar trend is followed by total phosphorus (TP) that reached maximum values (median $30 \mu \mathrm{g} \mathrm{P} \mathrm{L}^{-1}$ ) in April 2009 at the maximum extent of the bloom, when the dissolved reactive phosphorus (DRP) concentrations were very low (median $2 \mu \mathrm{g} \mathrm{P} \mathrm{L}{ }^{-1}$ ). The percentage of dissolved reactive phosphorus on the total increased from April 2009 ( 6\%) to October 2009 ( 46\%). This suggests that during the bloom, most of the phosphorus had been up taken by the P. rubescens cells, while after the bloom, a conspicuous amount of this nutrients remained dissolved and not assimilated. Total nitrogen (TN) followed a trend like that of total phosphorus, with maximum values (median $2.3 \mathrm{mg} \mathrm{N} \mathrm{L}^{-1}$ ) detected in April 2009. However, unlike phosphorus, most of the nitrogen was present in dissolved inorganic forms that always covered more than half of the total (54-78\% of the median values). In all the four field campaigns the phytoplankton population was strongly limited by phosphorus with the median TN/TP molar ratio (Table 3) between 78 and 89, largely higher than the optimum ratio $(16: 1)$ for phytoplankton growth $[1,68]$. Silica $\left(\mathrm{SiO}_{2}\right)$ concentrations were always above $3.0 \mathrm{mg} \mathrm{L}^{-1}$ (Table 3), indicating a consistent availability of this nutrient for the Bacillariophyceae population [69]. The profile of the P-chl-a concentrations (Figure 2, upper left panel) in April 2009 shows the formation of a subsurface maximum of around $38 \mu \mathrm{g} \mathrm{L}^{-1}$ (T-chl-a $=41 \mu \mathrm{g} \mathrm{L}^{-1}$ ) centered within the incipient thermocline at $2.7 \mathrm{~m}$ (Figure 2, upper right panel), with water temperatures of $12.5^{\circ} \mathrm{C}$. The P-chl-a maximum occurred at the 
limit of the nominal euphotic zone with a residual photosynthetically available radiation (PAR) of less than $1 \mu \mathrm{mol} \mathrm{m} \mathrm{s}^{-1}$ (Figure 2, lower right panel). Within the first $2.5 \mathrm{~m}$ of the water column, the highest values of TP (Figure 2, lower right panel) were also measured (63-64 $\mu \mathrm{g} \mathrm{P} \mathrm{L} \mathrm{L}^{-1}$ ) while the DRP concentrations were very low over the whole water column (2 $\mu \mathrm{g} \mathrm{P} \mathrm{L}^{-1}$, Table 2).
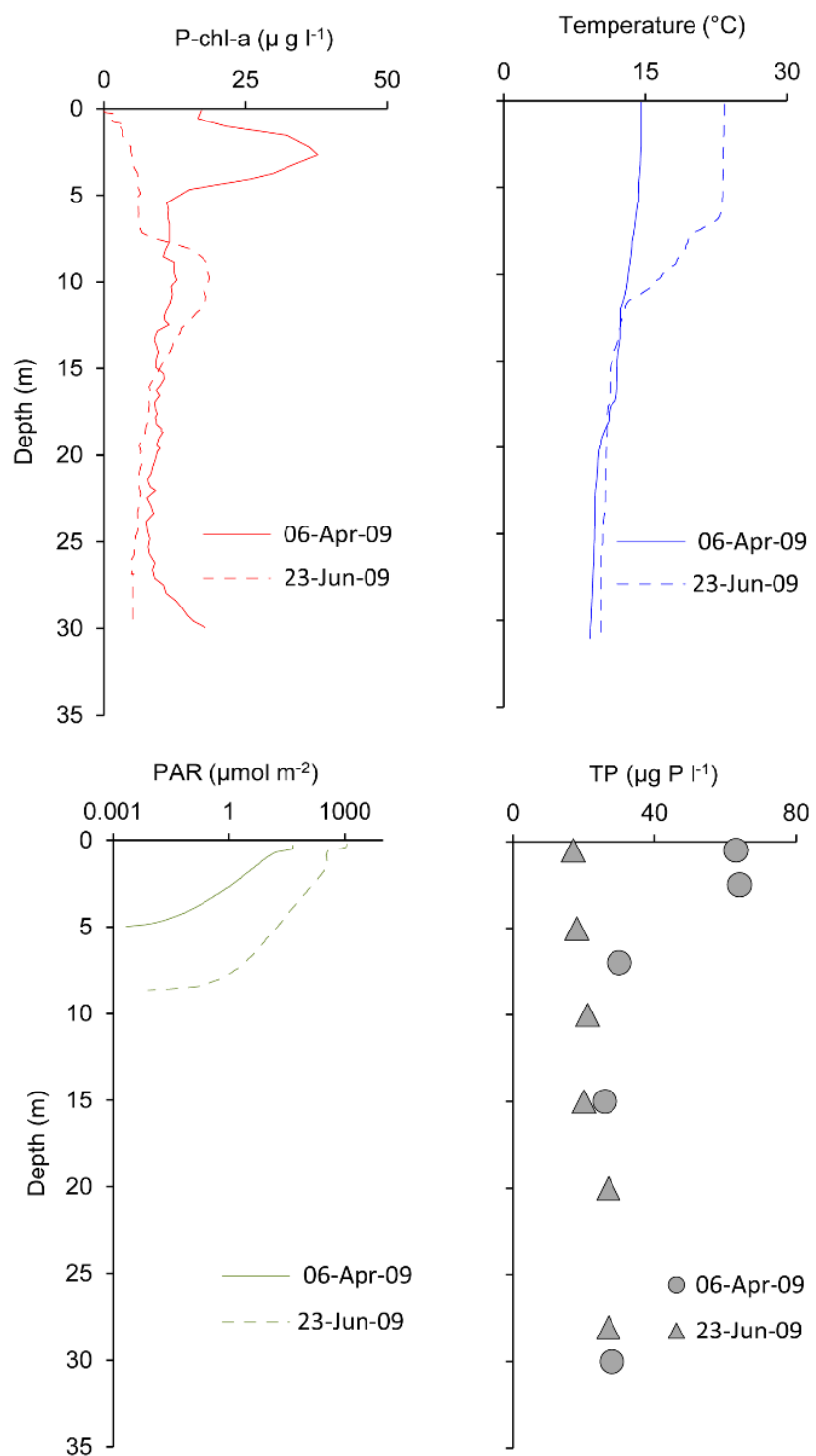

Figure 2. Profiles of temperature, PAR (logarithmic scale), P-chl-a and TP measured at station St6 on 6 April 2009 and 23 June 2009.

In June, the P-chl-a peak moved deeper, forming a clear deep chlorophyll maximum [30] located within a well-established thermocline between 7 and $16 \mathrm{~m}$ depth. Maximum P-chl-a values of $19 \mu \mathrm{g} \mathrm{L}^{-1}$ (T-chl-a $=21 \mu \mathrm{g} \mathrm{L}{ }^{-1}$ ) were recorded at $9.5 \mathrm{~m}$, where temperatures of about $16^{\circ} \mathrm{C}$ were measured. The chlorophyll-a maximum was centered below the nominal depth of the euphotic zone located at around $5 \mathrm{~m}$ (residual PAR of $11 \mu \mathrm{mol} \mathrm{m} \mathrm{s}^{-1}$ ). At $7 \mathrm{~m}$, the incident PAR was close to $1 \mu \mathrm{mol} \mathrm{m} \mathrm{s}^{2}$, while below $8 \mathrm{~m}$, the PAR signal was no longer detectable. TP concentrations were between 17 (surface) and 27 (bottom) $\mu \mathrm{g} \mathrm{P} \mathrm{L}^{-1}$, but, unlike April, they did not show any increase in the proximity of the chlorophyll-a peak. DRP concentrations increased slightly at around $4-5 \mu \mathrm{g} \mathrm{P} \mathrm{L}{ }^{-1}$ (Table 2), possibly indicating a decrease in the phosphorus uptake by the $P$. rubescens cells. 
In both the April and June 2009 field campaigns, the bloom extended longitudinally between approximately station St2 and St11 (Figure 3).

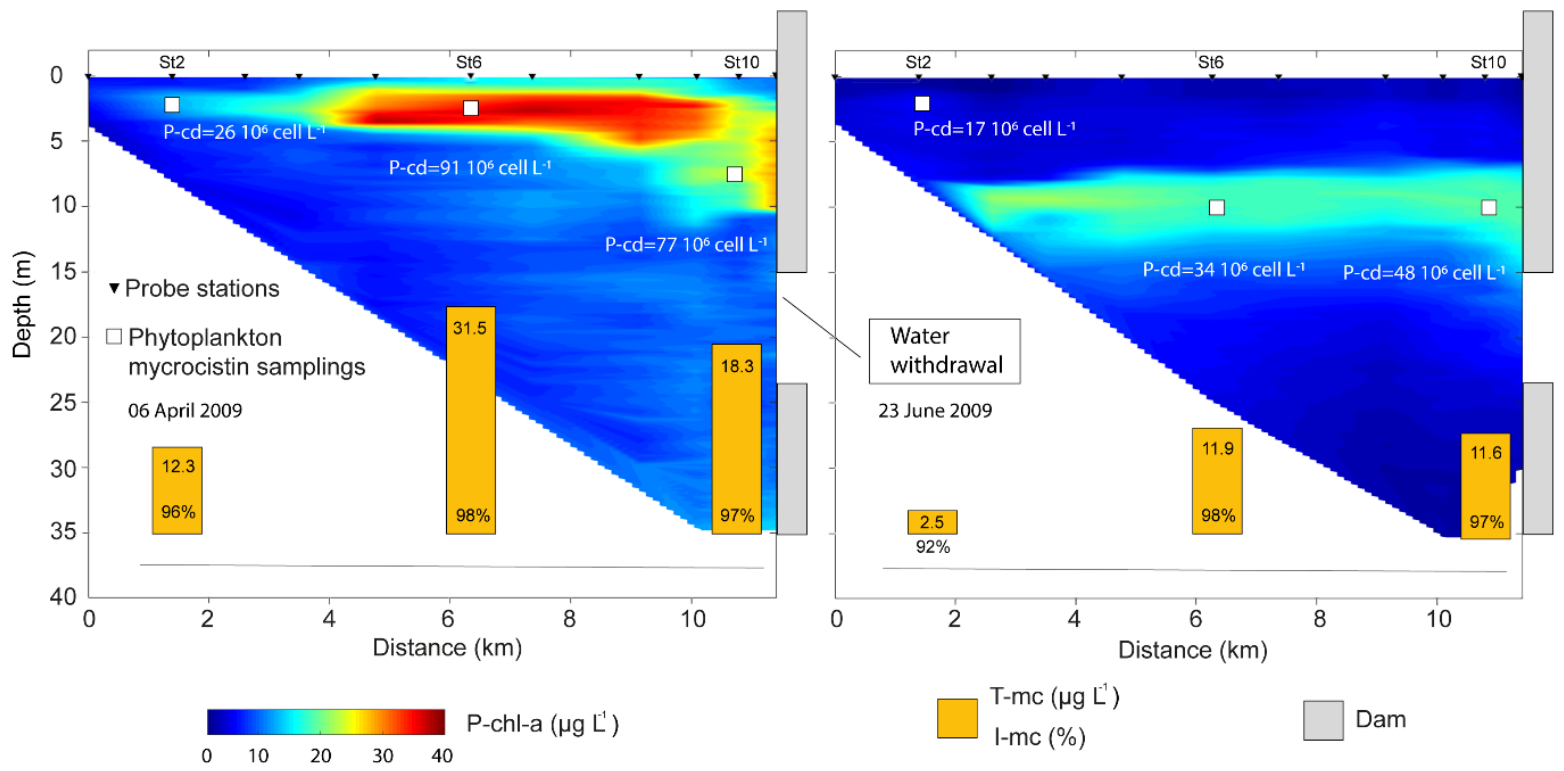

Figure 3. Contours show the distribution of the P. rubescens chl-a (P-chl-a, $\left.\mu \mathrm{g} \mathrm{L}^{-1}\right)$ concentrations over the south-north transect on 6 April 2009 (left panel) and on 26 June 2009 (right panel), with indication of the P. rubescens cell density (P-cd, cell $\mathrm{L}^{-1}$ ) at the P-chl-a peak in stations St2, St6, and St10. Bars indicate total microcystin (T-mc, $\mu \mathrm{g} \mathrm{L}^{-1}$ ) concentrations and the percentage of intracellular microcystins (I-mc, \%) at the peak of P-chl-a. Microcystin and cell density samples were collected at the depths of 2, 2.5, and $7 \mathrm{~m}$ on 6 April 2009 and 2.5, 10, and $10 \mathrm{~m}$ on 26 June 2009, at station St2, St6, and St10.

In April (Figure 3, left panel) the highest P-chl-a concentrations $\left(\approx 40 \mu \mathrm{g} \mathrm{L}^{-1}\right)$ were detected between station St5 and station St 10 at about $2.5 \mathrm{~m}$. At the P-chl-a peak, P. rubescens cell densities were between 26 and $91 \times 10^{6}$ cell L ${ }^{-1}$ with corresponding total microcystin concentrations in a range of 12.3-31.5 $\mu \mathrm{g} \mathrm{L}{ }^{-1}$. In June (Figure 3, right panel), P-chl-a peaked deeper at about $10 \mathrm{~m}$ and extended more continuously from the southern region of the lake (St3) to the dam (St11) with maximum P-chl-a concentrations close to $20 \mu \mathrm{g} \mathrm{L}{ }^{-1}$. P. rubescens cell densities were between 17 and $48 \times 10^{6}$ cell $\mathrm{L}^{-1}$, with corresponding total microcystin concentrations in a range of $2.5-11.9 \mu \mathrm{g} \mathrm{L}^{-1}$. At the northern edge of the lake, between station St10 and St11, P-chl-a in April accumulated in the upper part of the dam due to the lower flow rate $\left(2-3 \mathrm{~m}^{3} \mathrm{~s}^{-1}\right)$, while in June, the P-chl-a pattern appears closer to the opening and more stretched by the higher water withdrawal (about $25 \mathrm{~m}^{3} \mathrm{~s}^{-1}$ ).

[D-Asp ${ }^{3}$ ] microcystin-RR was the main microcystin present in the lake. Most (92-98\%) of the total microcystins (Figure 3) were contained in the P. rubescens cells (intracellar microcystins, I-mc), while extracellular microcystins (E-mc) were only residual (Figure 3). The highest dissolved microcystin concentrations $\left(0.7 \mu \mathrm{g} \mathrm{L}^{-1}\right)$ were detected in April 2009 at station St6 when the greatest intracellular content $\left(30.8 \mu \mathrm{g} \mathrm{L}^{-1}\right)$ of [D-Asp $\left.{ }^{3}\right] \mathrm{MC}-\mathrm{RR}$ was also measured. In this sample a limited amount of [D-Asp ${ }^{3}$ ] MC-LR $\left(<0.3 \mu \mathrm{g} \mathrm{L}^{-1}\right)$ was found. Between April and June 2009, it is possible to note a reduction of about $50 \%$ of the total microcystin concentration, in line with the P. rubescens biomass abatement. In the two further campaigns (October 2009 and April 2010), microcystin concentrations (not shown) were very low, with total microcystins in a range of $0.1-0.4 \mu \mathrm{g} \mathrm{L}^{-1}$.

In the six lake samples collected at the chlorophyll peak, in April and June 2009, a significant positive linear relationship (Figure 4, upper panel) was found between Pchl-a (range: 6.4-37.7 $\left.\mu \mathrm{g} \mathrm{L}^{-1}\right)$ and P. rubescens cell density $(\mathrm{r}=0.98 ; p$-value $<0.001$; 
RMSE $=5 \times 10^{6}$ cell $\mathrm{L}^{-1}$ ). In a P. rubescens cell density range of $17-91 \times 10^{6}$ cell $\mathrm{L}^{-1}$ the regression equation takes the form of Equation (2):

$$
\text { P-cd }=2.3433 \text { P-chl-a }+3.0148
$$
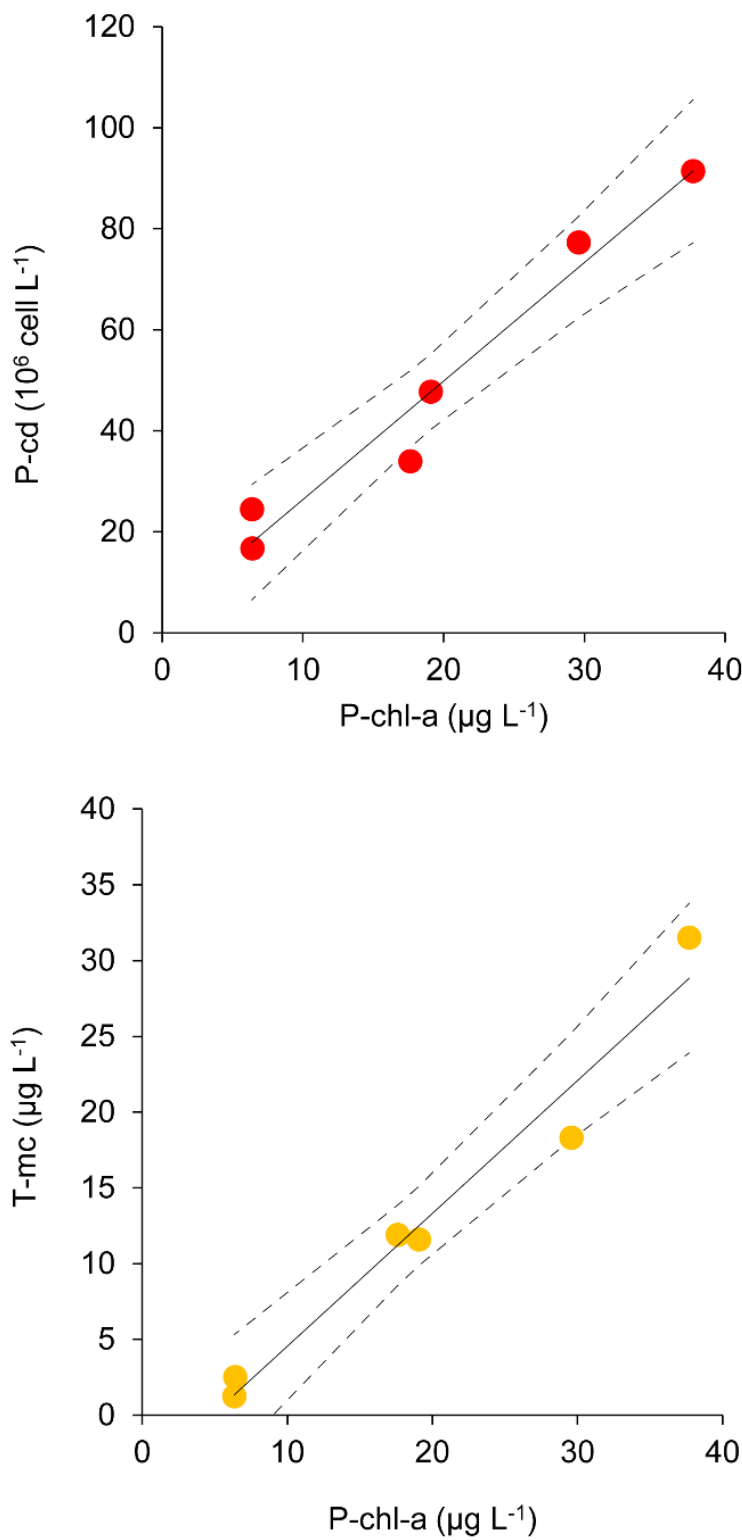

Figure 4. Upper panel linear regression (solid line) between P. rubescens chlorophyll-a content (P-chl-a) and P. rubescens cell density (P-cd). Dashed lines, 95\% confidence interval P-cd: $6.5-105 \times 10^{6}$ cell L $^{-1}$. Lower panel, linear regression (solid line) between P-chl-a and total microcystin (T-mc). Dashed lines, 95\% confidence interval 0-34 $\mu \mathrm{g} \mathrm{L}^{-1}$. Data refer to the P-chl-a peak in stations St2, St6, and St11 at a depth of 2, 2.5 and $7 \mathrm{~m}$ on 6 April 2009 and 2.5, 10, and $10 \mathrm{~m}$ on 26 June 2009.

P-chl-a also correlates positively (Figure 4 , lower panel) with total microcystins $\left(\mathrm{r}=0.98 ; p\right.$-value $\left.<0.001 ; \mathrm{RMSE}=1.9 \mu \mathrm{g} \mathrm{L}^{-1}\right)$. In a range of total microcystin concentration of 1.2-31.5 $\mu \mathrm{g} \mathrm{L}^{-1}$, the regression equation takes the form of Equation (3):

$$
\mathrm{T}-\mathrm{mc}=0.8767 \mathrm{P}-\mathrm{chl}-\mathrm{a}-4.225
$$


A significant relationship was also found between P-chl-a and intracellular $(\mathrm{r}=0.98$; $p$-value $<0.001$; RMSE $=1.9 \mu \mathrm{g} \mathrm{L}^{-1}$; range $=1.2-30.8 \mu \mathrm{g} \mathrm{L}-1$, not shown). Extracellular microcystin concentrations tended to increase with increasing P-chl-a concentrations but the two variables did not show any significant linear relationship (not shown).

\subsection{Lake Remote Sensing Monitoring}

Figure 5 shows nine spectral signatures (MERIS data) corresponding to nine lake stations (St1, St3, St4, St5, St7, St8, St9, St10, and St11) sampled on 06 Apr 2009 on Lake Occhito, before (Figure 5, left upper panel) and after (Figure 5, left lower panel) atmospheric correction. From Figure 5, the strong effect of the atmosphere on the MERIS signal can be noticed. The correction in particular reveals the presence of two marked peaks in Band $5(560 \mathrm{~nm})$ and Band $9(708 \mathrm{~nm})$ of the MERIS WLR, consistent with the spectral signature reported in Maltese et al. [49] We amplified the gap between the MERIS Band 9 $(708 \mathrm{~nm})$ and Band $8(681 \mathrm{~nm})$ data through the development of the normalized band ratio (WLRratio) algorithm reported in Equation (4):

$$
\mathrm{WLR}_{\text {ratio }}=(\mathrm{B} 9-\mathrm{B} 8) /(\mathrm{B} 9+\mathrm{B} 8)
$$
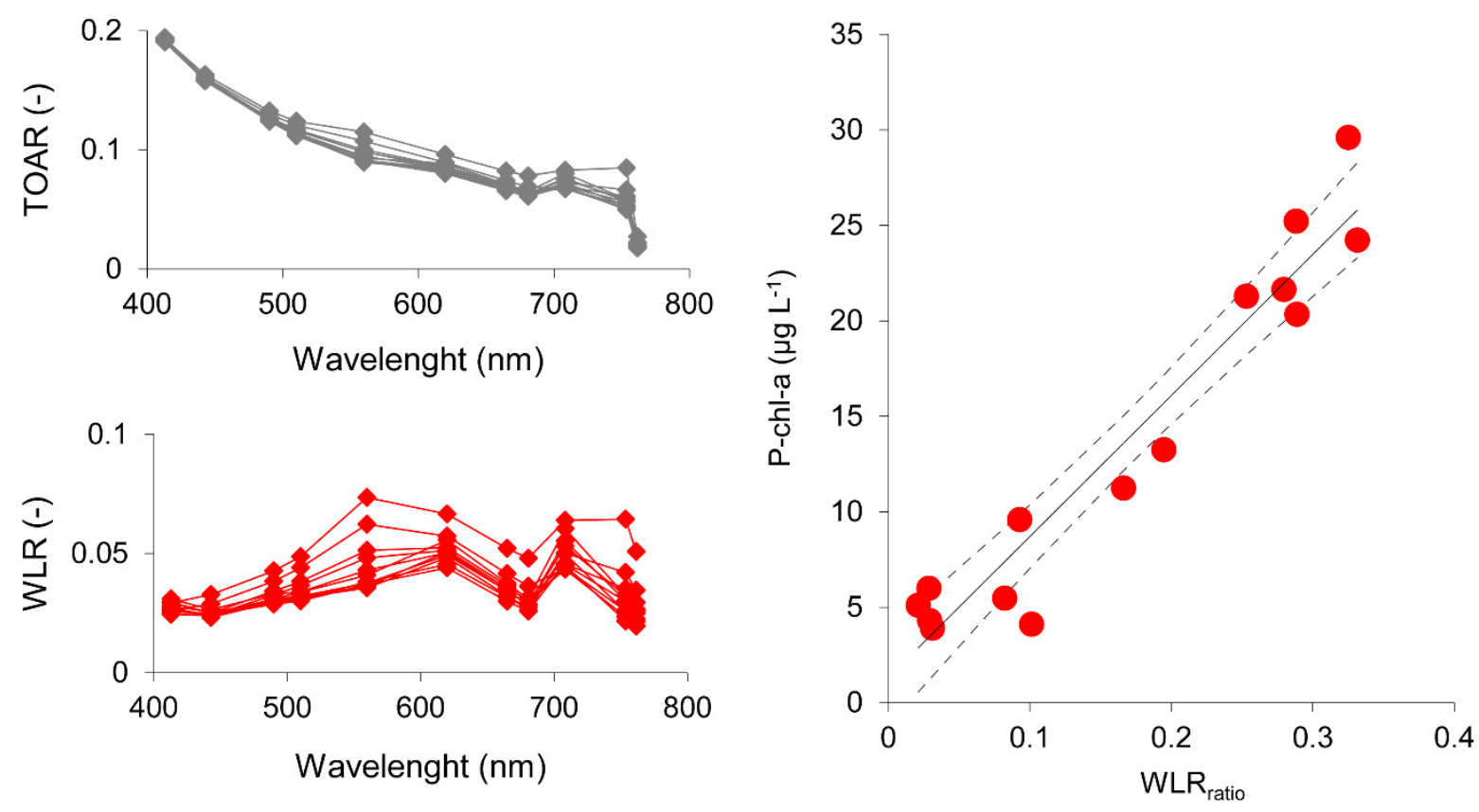

Figure 5. Left panels: spectral signatures of nine Lake Occhito sampling stations (St2, St3, St4, St5, St7, St8, St9, St10, and St11), before (upper panel) and after (lower panel) the atmospheric correction; TOA = Top Of Atmosphere Reflectance, WLR = Water Leaving Reflectance. Right panel: linear regression (solid line) between WLR $_{\text {ratio }}$ computed with Equation (1) and the P. rubescens chlorophyll-a (P-chl-a) concentrations measured in the field through multiple stations fluorometric profiles in the corresponding sampling stations. Dashed lines represent the $95 \%$ confidence interval, $\mathrm{P}-\mathrm{chl}-\mathrm{a}: 3-29 \mu \mathrm{g} \mathrm{L}^{-1}$.

$\mathrm{WLR}_{\text {ratio }}$ (range $\left.=0.120130 .3\right)$ resulted in being very well correlated $(\mathrm{r}=0.93$; $p$-value $<0.001$ ) with the concentrations of P-chl-a (range $=3.9-29.6 \mu \mathrm{g} \mathrm{L}^{-1} ; \mathrm{RMSE}=2 \mu \mathrm{g} \mathrm{L}^{-1}$ ) measured in 15 sampling stations of the south-north transect on 6 April and 23 June 2009. This allowed us to define the following Equation (5) of calibration:

$$
\text { P-chl-a }=73.871 \text { WLR }_{\text {ratio }}+1.316
$$

Equation (5) was used to estimate the surface (0-5 m) P-chl-a concentrations from the $W_{L R}$ ratio in each of the Lake Occhito MERIS cells used in this study (Figure 1). This allowed the development of lake-wide P-chl-a maps (Figure 6) having a spatial resolution 
of $300 \mathrm{~m}$ and describing the evolution of the bloom over the lake surface from its early beginning (January 2009) to its ending (October 2009). The use of Equations (2) and (3) furthermore allowed estimating of the corresponding values of $P$. rubescens cell density and total microcystin concentrations; the results are reported in Figure 6.
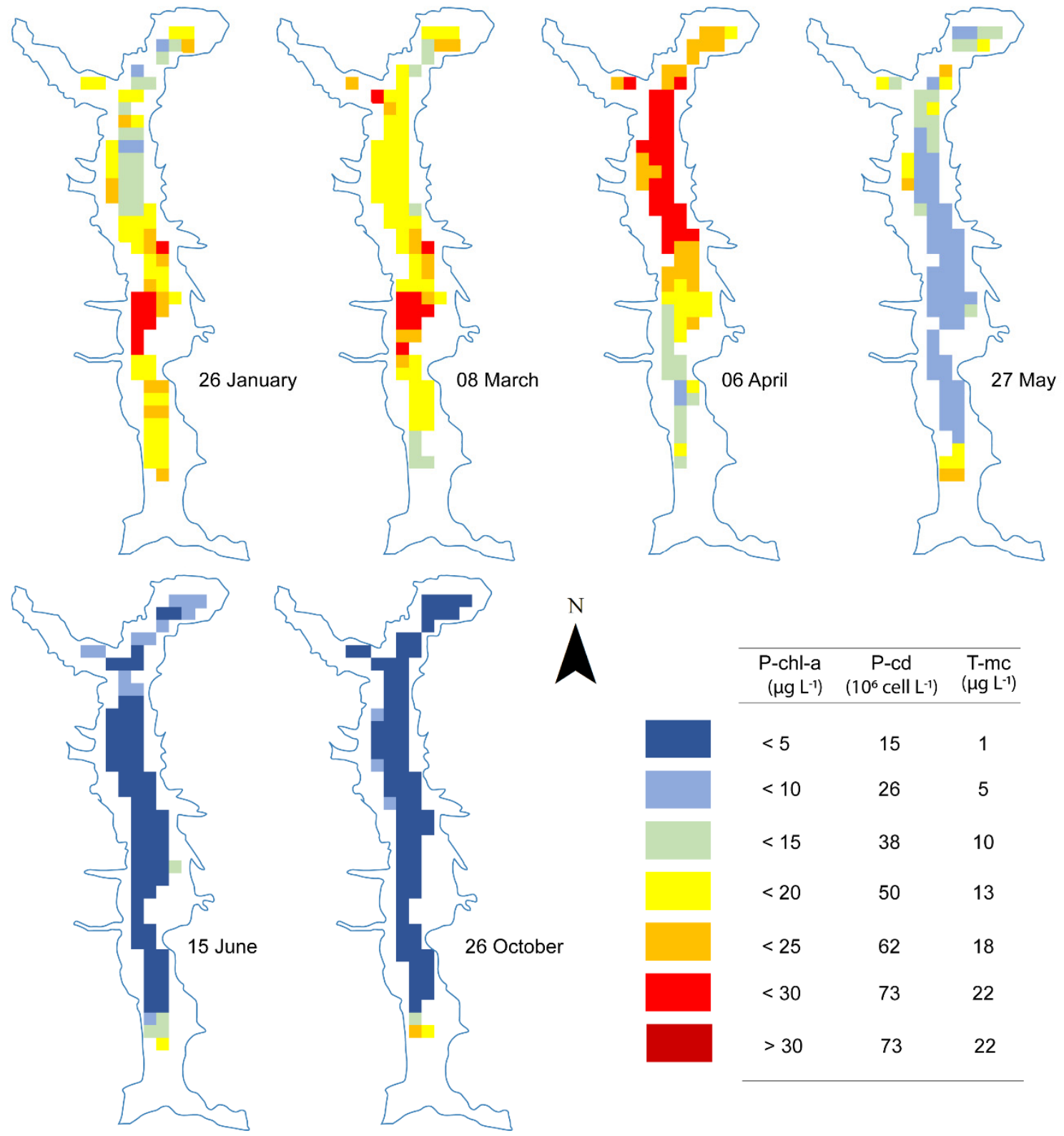

Figure 6. Maps of the P-chl-a $\left(\mu \mathrm{g} \mathrm{L}^{-1}\right)$ concentrations between the end of January and the end of October 2009. The period covers the beginning and the ending of the bloom. The figure legend also reports the corresponding P. rubescens cell density $\left(\mathrm{P}-\mathrm{cd}, 106\right.$ cell $\left.\mathrm{L}^{-1}\right)$ and total microcystin concentrations (T-mc, $\left.\mu \mathrm{g} \mathrm{L} \mathrm{L}^{-1}\right)$.

Between the end of January and the beginning of March 2009, the distribution of P-chla showed rather high values over the lake surface (Figure 6) with a maximum in the range of 25-30 $\mu \mathrm{g} \mathrm{L}^{-1}$ in the central part of the lake surface, corresponding to P. rubescens cell density in the range of $62-63 \times 10^{6}$ cell L ${ }^{-1}$, and total microcystin concentrations of $18-22 \mu \mathrm{g} \mathrm{L}^{-1}$. In April, the area with the highest P-chl-a concentrations appears more concentrated in the northern part of the lake, near the dam. In May, the P-chl-a surface concentration decreased markedly to values generally below $10 \mu \mathrm{g} \mathrm{L}^{-1}$ and in June to values below $5 \mu \mathrm{g} \mathrm{L}^{-1}$ with corresponding $P$. rubescens cell density lower than $15 \times 10^{6}$ cell $\mathrm{L}^{-1}$ and total microcystin 
concentrations below $1 \mu \mathrm{g} \mathrm{L}{ }^{-1}$. A very similar situation could be noticed at the end of October.

\subsection{Irrigation Network In Situ Measurements}

P. rubescens cell densities detected at the Finocchito splitter between April 2009 and April 2010 were in the range of $0.1-23 \times 10^{6}$ cell L $^{-1}$ (Table S3), with the maximum detected in April 2009 (Figure 7, upper panel). Then, the P. rubescens content decreased till October $2009\left(0.1 \times 10^{6}\right.$ cell L $\left.{ }^{-1}\right)$, showing a trend like that detected in the lake. From November 2009 the $P$. rubescens presence increased till January 2010 when a small peak $\left(2.2 \times 10^{6}\right.$ cell L $\left.{ }^{-1}\right)$ was detected (Figure 7, upper panel). After January, P. rubescens cell densities decreased again to values of about 1.2-1.3 $\times 10^{6}$ cell $\mathrm{L}^{-1}$.
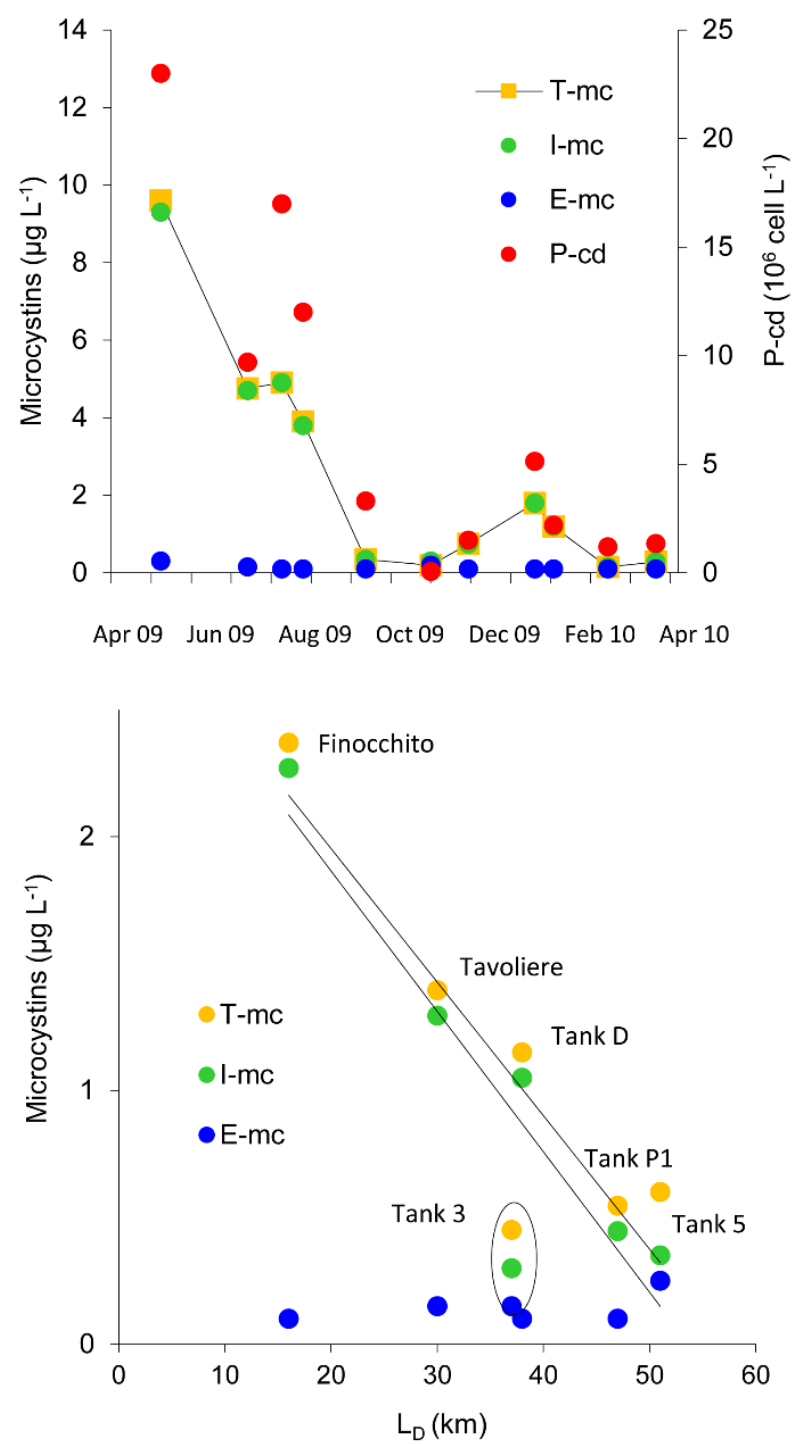

Figure 7. Upper panel: trend of the P. rubescens cell density (right scale) and of the microcystin concentrations (left scale) in the Finocchito splitter between April 2009 and April 2010. Lower panel: trend of the median microcystin concentrations distinguishing in total (T-mc) intracellular (I-mc) and extracellular (E-mc). Circle indicates the "anomalous" data related to Tank 3.

A similar trend was followed by microcystin concentrations (T-mc $=0.3-9.6 \mu \mathrm{g} \mathrm{L}^{-1}$ ) with maximum values of total microcystin concentrations $\left(9.6 \mu \mathrm{g} \mathrm{L}^{-1}\right)$ of about $52 \%$ of the values detected at the P-chl-a peak in station St10 $\left(18.3 \mu \mathrm{g} \mathrm{L}^{-1}\right)$. After April 2009, total microcystin concentrations decreased but remained above $4 \mu \mathrm{g} \mathrm{L} \mathrm{L}^{-1}$ up to August; 
minimum concentrations were reached in October $2009\left(0.2 \mu \mathrm{g} \mathrm{L}{ }^{-1}\right)$. Subsequently, the microcystin concentrations increased again till the end of January 2010 when values of $1.8 \mu \mathrm{g} \mathrm{L}^{-1}$ were detected. Then, total microcystin concentrations decreased to values of about $0.2-0.3 \mu \mathrm{g} \mathrm{L}^{-1}$. As in the lake, most of the microcystin was contained in the $P$. rubescens cells $\left(\mathrm{I}-\mathrm{mc}=0.3-9.3 \mu \mathrm{g} \mathrm{L}^{-1}\right.$ ) with extracellular microcystin concentrations in a range of only $0.1-0.3 \mu \mathrm{g} \mathrm{L}^{-1}$ (Table S3).

During the synoptic campaign conducted between June and November 2009 on six relevant tanks of the irrigation network (including the Finocchito Splitter), total microcystin concentrations were in the range of $0.4-5 \mu \mathrm{g} \mathrm{L}^{-1}$, with the highest concentrations detected (in June) in the Finocchito splitter (Table S4). Based on the median of the total microcystin concentrations (Table S4), the tanks of the irrigation network can be ranked as follows: Finocchito $\left(2.4 \mu \mathrm{g} \mathrm{L}^{-1}\right)>$ Tavoliere $\left(1.4 \mu \mathrm{g} \mathrm{L}^{-1}\right)>$ Tank D $\left(1.2 \mu \mathrm{g} \mathrm{L}^{-1}\right)>$ Tank 5 $\left(0.6 \mu \mathrm{g} \mathrm{L}^{-1}\right)>$ Tank P1 $\left(0.5 \mu \mathrm{g} \mathrm{L}^{-1}\right) \sim$ Tank $3\left(0.5 \mu \mathrm{g} \mathrm{L}^{-1}\right)$, with a reduction of about $80 \%$ of the microcystin content from the Finocchito splitter to the furthest tanks of the irrigation system (Tank P1 and Tank 3). In all the tanks, most of the microcystin was within the $P$. rubescens cells, with intracellular microcystin percentages in the range of $58-96 \%$ of the total (Table S4). Extracellular microcystin concentrations were much lower and constrained in a rather narrow range of $0.1-0.7 \mu \mathrm{g} \mathrm{L}{ }^{-1}$. A significant negative linear relationship $(\mathrm{r}=0.90$; $p$-value $<0.001$ ) was found between the median of the total microcystin concentrations detected during the synoptic campaign and the distance from the lake (Figure 7, lower panel). At a distance range of $16-51 \mathrm{~km}$, the trend of the median total microcystin concentrations is described by the following Equation (6):

$$
\mathrm{T}-\mathrm{mc}=-0.0532 \mathrm{~L}_{\mathrm{D}}+3.0974
$$

A very similar relationship $(\mathrm{r}=0.91 ; p$-value $<0.001)$ was observed for intracellular microcystins whose concentrations were described as follows in Equation (7):

$$
\mathrm{I}-\mathrm{mc}=-0.0564 \mathrm{~L}_{\mathrm{D}}+3.1058
$$

Both equations indicate a reduction of about $0.05 \mu \mathrm{g} \mathrm{L} \mathrm{L}^{-1} \mathrm{~km}^{-1}$ in the irrigation network. The data related to Tank 3 (circle in the lower panel of Figure 7) underline a lower contribution of intracellular microcystins compared to the other tanks located at a similar distance from the lake (e.g., Tank D, Table S1).

\section{Discussion}

The availability of fresh water characterized by high chemical and biological quality standards is one of the main factors limiting social and economic development of modern societies [70]. The problem is particularly stringent in drought areas with limited rainfall, such as south Italy [71]. In these zones, reservoirs are often strategic and precious resources of water [72]. One of the main threats affecting reservoirs is the proliferation of harmful cyanobacteria (HCBs), whose presence can compromise the water usages and the delivery of ecosystem services [11-13].

In the presence of cyanobacteria blooms, the monitoring of the water bodies must be intensified in terms of both frequency, and spatial distribution of samplings. Monitored variables must include nutrients, algal biomass, and cyanotoxins [11]. International [11,73,74] and national [75,19 for Italy] authorities have defined guidelines and procedures for the management of cyanobacterial blooms. Limitations in the use of the water resource are generally based on the quantity (e.g., cell density) of toxic species, but above all on the concentrations of cyanotoxins. Depending on the final use of the water resource, specific thresholds of cyanotoxin concentrations have been established. For microcystins, a concentration of $1 \mu \mathrm{g} \mathrm{L}^{-1}$ is considered safe for human consumption [74,75], while a concentration of $25 \mu \mathrm{g} \mathrm{L}^{-1}$ is judged sufficiently protective for bathing [19,73]. The use of water contaminated by microcystins for irrigation is very frequent all over the world. Nevertheless, the available guidelines generally do not include any threshold value for these natural 
toxins [76]. This gap is problematic if we consider that the presence of microcystin in the irrigation waters may cause damages to the crops and accumulation of the toxins in the edible parts of the cultivated plants [33,76-79].

The monitoring of cyanobacteria in reservoirs and their downstream distribution systems (e.g., irrigation, drinking water supply) is a challenging task having important repercussions on public health [11]. For the monitoring of these integrated systems, official guidelines generally refer to traditional laboratory methods, but also suggest the use of complementary approaches to improve the sampling rate and spatial resolution of the measurements. These approaches include in situ real-time monitoring systems and remote sensing techniques $[11,75]$.

The data collected in this study highlight that during the bloom, the phytoplankton population was completely dominated by $P$. rubescens that congested the whole ecosystem, absorbing all the bioavailable phosphorus and assimilating this nutrient within its own cells. The integration of in situ fluorometric data of P. rubescens chlorophyll-a content, with both laboratory and remote sensing data, allowed us to obtain $300 \mathrm{~m}$ resolution maps of several variables including $P$. rubescens chlorophyll-a, cell density $(\mathrm{P}-\mathrm{cd})$ and total microcystins (T-mc), and thus to follow the evolution of the P. rubescens bloom over the lake surface (Figure 6). In particular, the maps related to microcystin concentrations were sufficiently accurate to be of interest for the management of both drinking water supply $\left(1 \mu \mathrm{g} \mathrm{L}^{-1}\right)$ and bathing $\left(25 \mu \mathrm{g} \mathrm{L}^{-1}\right)$. The main limit in the monitoring of P. rubescens via remote sensing is related to the capability of this species to bloom deeply in the water column during summer (Figures 2 and 3). This is particularly relevant if we consider that the opening for water withdrawal in reservoirs is often located at a fixed depth from the lake bottom. The water withdrawal can therefore intercept water layers characterized by the presence of $P$. rubescens cells and thus containing microcystins (Figure 2). In these cases, a direct and continuous monitoring of the bloom using fluorometric sensors [80], distributed over the water column in the proximity of the dam, would furnish precious management information. To optimize the quality of the water withdrawn, these measurement systems should be integrated with selective devices able to regulate the withdrawal depth [81]. The fluorometric data collected at the surface, furthermore, could be used to implement a remote sensing calibration/validation system, based, for instance, on artificial intelligence techniques, such as machine learning procedures $[80,82,83]$. These applications are particularly promising from a management point of view as the approach presented in this study is highly site specific [48]. This is due to two main reasons. First, because the monitoring of the cyanobacteria biomass via remote sensing depends not only on the spectral features of the cyanobacteria species, but also on the overall reflectance of the lake, including the influence of the surrounding environment [83,84]. Second, because the relationship between the cyanobacteria biomass and the microcystin production is also site dependent [34].

Focusing on the irrigation network, as far as the authors know, this is the first study describing the trend of the microcystin concentrations in a large complex agricultural system during a cyanobacteria bloom. At the first tank downstream, the reservoir's (Finocchito splitter) total microcystin concentrations remained above $4 \mu \mathrm{g} \mathrm{L}^{-1}$ (Figure 6) from April to August 2009, and thus for most of the irrigation season, which finished at the end of November. These concentrations can determine damages to different crops and potentially induce microcystin accumulation within edible parts of cultivated plants [76] However, our results show that the microcystin concentrations in the irrigation network tend to linearly decrease with the distance from the lake (about $0.05 \mu \mathrm{g} \mathrm{L}^{-1} \mathrm{~km}^{-1}$ ), probably because of different environmental stressors that may favor the death of the cells and their lysis. P. rubescens, in fact, is a species adapted to live at low temperatures and at low levels of solar radiation, proliferating in lakes of a certain depth where a stable summer thermal stratification can develop, allowing this species to take refuge deep into the metalimnion in the warmest and sunniest periods of the year [9]. This mechanism of defense cannot be adopted by P. rubescens in the irrigation network, neither in the open channels nor in the 
shallowest tanks, having depths even lower than $1 \mathrm{~m}$ (e.g., Tank P1 and Tank 5). In addition to the higher water temperatures and solar radiation, in the irrigation network, P. rubescens cells encounter also high mechanical stresses and water turbulence that can favor the cell lysis. All these stressors contribute to the decrease of internal microcystin concentrations with the distance from the lake. Internal microcystins are the major contributors to the total microcystin content [34]. After cell lysis, the half-life times of microcystins vary between 2.5 and 20 days depending on the environmental conditions [10]. Outside the cell, therefore, microcystins can be quickly degraded in the water environment. This explains why, both in the lake and in the distribution network, the concentrations of external microcystins were always rather low. The irrigation system itself thus seems to have some structural features limiting the proliferation of $P$. rubescens in its tanks and consequently the risk associated with the bloom. As a result, the farthest tanks showed a reduction of about $80 \%$ in the microcystin content compared to the Finocchito splitter. The particularly low microcystin concentrations found in Tank 3, instead, are more difficult to explain. Tank 3, in fact, is the deepest tank sampled in this study and consequently should provide a more favorable environment for the growth of $P$. rubescens. Nevertheless, it is possible to hypothesize that the $P$. rubescens cells experienced high level of stress before reaching Tank 3 . This was likely mediated by the long stretch of the open channel connecting this tank to the Finocchito splitter (Figure 1). Overall the microcystin concentrations in the proper irrigation network were generally sufficiently low to avoid crop damages (Table S4). The results of this study, therefore, suggest that to mitigate the proliferation of $P$. rubescens, the irrigation networks should be designed to favor the solar irradiation of tanks and channels, for example, preferring open channels instead of covered ones, such as tunnels. Furthermore, the water flow in the irrigation network should be kept as turbulent as possible. The installation of mixing devices in the deepest tanks could also be taken into consideration to avoid the stratification of the tank's water column and the proliferation of this species in its interior.

Finally, one possible way to monitor the spread of the P. rubescens over the irrigation network in a continuous fashion is the installation of fluorometric sensors within the main tanks. This would provide relevant data for the real-time management of the water resource. These fluorometric data could also be related to the next generation of high spatial resolution satellite sensors having dedicated bands for cyanobacteria (e.g., Sentinel2 next generation, [82]) to monitor tanks of few tens of meters in size. In addition, a new generation of hyperspectral data (e.g., PRISMA and DESIS) with a high number of contiguous spectral narrow bands that highlight specific absorption features can also be used to select and empirically calibrate or modify broad band indices, providing a link between hyperspectral and multispectral datasets [85-87].

\section{Conclusions}

The results presented in this paper form an original contribution on how cyanobacteria blooms develop in multiple-uses reservoirs. In particular, the paper presents precious and rarely available data on the bloom spread over the main tanks of an irrigation network. These data suggest that the cyanobacteria population (specifically $P$. rubescens) suffers outside the reservoir environment and that its presence tends to decrease with the distance from the reservoir. The approach presented in the manuscript clearly supports the hints present in both international and national guidelines suggesting the integration of laboratory, real-time in situ, and remote sensing data. Laboratory data are still indispensable for the direct measurements of specific biological (i.e., cyanobacteria cell densities) or chemical (i.e., nutrients or cyanotoxins) variables. Nevertheless, direct in-situ (e.g., fluorometric data) and remote sensing measurements (e.g., reflectance) provide proxy variables that can be integrated in measurement programs to improve the frequency and the spatial resolution of the acquired data. The general approach of this study can be transferred to other environments, but not the specific algorithms presented in this paper, which need to be defined for each specific environment as both remote sensing algorithms and cyanobacteria-biomass-microcystin-production relationships are site specific. 
Supplementary Materials: The following are available online at https:/ / www.mdpi.com/article/ 10.3390/w13162162/s1, Table S1: Morphometric features of the irrigation network fed by the Lake Occhito waters; Figure S1: Relationships between biovolume and chlorophyll-a related to the total phytoplankton assemblage; Table S2: List of species detected in Lake Occhito; Table S3: Statistics of the $P$. rubescens cell density and microcystins concentrations detected in the Finocchito tank; Table S4: Statistics of the microcystins concentrations detected in the synoptic campaign carried out in the main tanks of the irrigation network.

Author Contributions: Conceptualization, D.C., R.M., L.G. and M.B.; methodology, D.C., R.M. and L.G.; investigation, D.C., R.M. and L.G.; data curation, D.C., R.M. and L.G.; writing-original draft preparation, D.C., R.M. and L.G.; writing-review and editing, D.C., R.M., L.G. and M.B.; supervision, D.C. All authors have read and agreed to the published version of the manuscript.

Funding: This research was funded by the Consorzio per la Bonifica della Capitanata within the agreement: "Convenzione tra il Consorzio per la Bonifica della capitanata e 1'IRSA-CNR. Gestione dell'emergenzaFioriture di Planktothrix rubescens in funzione dell'uso irriguo".

Institutional Review Board Statement: Not applicable.

Informed Consent Statement: Not applicable.

Data Availability Statement: Not applicable.

Acknowledgments: The authors wish to thank Giuseppe Dinunzio and Alfredo Pitullo (Consorzio per la Bonifica della Capitanata) for their support and precious information on the functioning of the integrated hydraulic system managed by the Consorzio. We are also grateful to our colleagues at the Water Research Institute, National Research Council of Italy: Nicolas Guyennon, Fiorenzo Pozzoni, Gianni Tartari, and Lucia Valsecchi for their precious suggestions and for helping us in the field and laboratory activities carried out in the present research. We finally thank two anonymous reviewers for their suggestions that greatly improved the quality of this manuscript.

Conflicts of Interest: The authors declare no conflict of interest.

$\begin{array}{ll}\text { Abbreviations } \\ \text { AOT } & \text { Aerosol Optical Thickness } \\ \text { Ch-chl-a } & \text { Chlorophytes chlorophyll-a } \\ \text { Cond } & \text { Electrical Conductivity } \\ \text { Cr-chl-a } & \text { Cryptophyta chlorophyll-a } \\ \text { D-chl-a } & \text { Diatoms chlorophyll-a } \\ \text { DO } & \text { Dissolved Oxygen } \\ \text { Dr } & \text { Depth range } \\ \text { DRP } & \text { Dissolved Reactive Phosphorus } \\ \text { E-mc } & \text { Extracellular microcystins } \\ \text { HCB } & \text { Harmful Cyanobacteria Bloom } \\ \text { I-mc } & \text { Intracellular microcystins } \\ \text { LOQ } & \text { Limit of Quantification } \\ \text { MERIS } & \text { Medium Resolution Imaging Spectrometer } \\ \text { MODIS } & \text { Moderate Resolution Imaging Spectrometer } \\ \text { N } & \text { Number of samples } \\ \text { N-NH } & \text { Ammonium } \\ \text { N-NO } & \text { Nitrate } \\ \text { OLS } & \text { Ordinary Least Squares } \\ \text { P-\% } & \text { Percentage of P. rubescens to the total biovolume } \\ \text { PAR } & \text { Photosynthetically Available Radiation } \\ \text { P-cd } & \text { P. rubescens cell density } \\ \text { P-chl-a } & \text { P. rubescens chlorophyll-a } \\ \text { QQ } & \text { Quantile Quantile }\end{array}$




$\begin{array}{ll}\text { SI } & \text { Shannon Index } \\ \mathrm{SiO}_{2} & \text { Silica } \\ \text { SMAC } & \text { Simplified Method for Atmospheric Corrections } \\ \text { T-bv } & \text { Total biovolume } \\ \text { T-chl-a } & \text { Total chlorophyll-a } \\ \text { Temp } & \text { Temperature } \\ \text { TIN } & \text { Total Inorganic Nitrogen } \\ \text { T-mc } & \text { Total microcystin } \\ \text { TN } & \text { Total Nitrogen } \\ \text { TOA } & \text { Top Of Atmosphere reflectance } \\ \text { TP } & \text { Total Phosphorus } \\ \text { WLR } & \text { Water Leaving Reflectance } \\ \text { WLRratio } & \text { Water Leaving Reflectance ratio }\end{array}$

\section{References}

1. Dokulil, M.T.; Teubner, K. Cyanobacterial dominance in Lakes. Hydrobiologia 2000, 438, 1-12. [CrossRef]

2. Zhang, M.; Duan, H.; Shi, X.; Yu, Y.; Kong, F. Contributions of meteorology to the phenology of cyanobacterial blooms: Implications for future climate change. Water Res. 2012, 46, 442-452. [CrossRef]

3. Huisman, J.; Codd, G.A.; Paerl, H.W.; Ibelings, B.W.; Verspagen, J.M.H.; Visser, P.M. Cyanobacterial blooms. Nat. Rev. Microbiol. 2018, 16, 471-483. [CrossRef] [PubMed]

4. Carraro, E.; Guyennon, N.; Viviano, G.; Manfredi, E.C.; Valsecchi, L.; Salerno, F.; Tartari, G.; Copetti, D. 16-Impact of global and local pressures on the ecology of a medium-sized pre-Alpine Lake. In Developments in Environmental Modelling; Ferenc, J., Sven Erik, J., Eds.; Elsevier: Amsterdam, The Netherlands, 2012; Volume 25, pp. 259-274, ISBN 0167-8892.

5. Taranu, Z.E.; Gregory-Eaves, I.; Leavitt, P.R.; Bunting, L.; Buchaca, T.; Catalan, J.; Domaizon, I.; Guilizzoni, P.; Lami, A.; McGowan, S.; et al. Acceleration of cyanobacterial dominance in north temperate-subarctic Lakes during the Anthropocene. Ecol. Lett. 2015, 18, 375-384. [CrossRef]

6. Shi, K.; Zhang, Y.; Zhou, Y.; Liu, X.; Zhu, G.; Qin, B.; Gao, G. Long-term MODIS observations of cyanobacterial dynamics in Lake Taihu: Responses to nutrient enrichment and meteorological factors. Sci. Rep. 2017, 7, 40326. [CrossRef]

7. Copetti, D.; Salerno, F. Climate-Water-Ecosystem-Interactions: Insights from four continent's case studies. Water 2020, 12, 1445. [CrossRef]

8. Paerl, W.; Huisman, J. Climate Change: A catalyst for global expansion of harmful cyanobacterial blooms. Environ. Microbiol. Rep. 2009, 1, 27-37. [CrossRef]

9. Reynolds, C.S. The Ecology of Phytoplankton. In Ecology, Biodiversity, and Conservation; Adam, P., Ed.; Cambridge University Press: Cambridge, UK; New York, NY, USA; Melbourne, Australia; Madrid, Spain; Cape Town, South Africa; Singapore; São Paulo, Brazil, 2006; ISBN 978-0-521-84413-0.

10. Chorus, I. (Ed.) Cyanotoxins Occurrence, Causes, Consequences; Springer: Berlin, Germany, 2001.

11. WHO. Toxic Cyanobacteria in Water: A Guide to Their Public Health Consequences, Monitoring and Management; Chorus, I., Ed.; E \& FN Spon: London, UK; New York, NY, USA, 1999; ISBN 0-419-23930-8.

12. Svrcek, C.; Smith, D.W. Cyanobacteria toxins and the current state of knowledge on water treatment options: A review. J. Environ. Eng. Sci. 2004, 3, 155-185. [CrossRef]

13. Zamyadi, A.; MacLeod, S.L.; Fan, Y.; McQuaid, N.; Dorner, S.; Sauvé, S.; Prévost, M. Toxic cyanobacterial breakthrough and accumulation in a drinking water plant: A monitoring and treatment challenge. Water Res. 2012, 46, 1511-1523. [CrossRef]

14. Ernst, B.; Hoeger, S.J.; O'Breien, E.; Dietrich, D.R. Abundance and toxicity of Planktothrix rubescens in the pre-alipine Lake Ammersee. Harmful Algae 2009, 8, 329-342. [CrossRef]

15. Posch, T.; Köster, O.; Salcher, M.M.; Pernthaler, J. Harmful filamentous cyanobacteria favoured by reduced water turnover with lake warming. Nat. Clim. Chang. 2012, 2, 809-813. [CrossRef]

16. Jacquet, S.; Kerimoglu, O.; Rimet, F.; Paolini, G.; Anneville, O. Cyanobacterial bloom termination: The disappearance of Planktothrix rubescens from Lake Bourget (France) after restoration. Freshw. Biol. 2014, 59, 2472-2487. [CrossRef]

17. Copetti, D.; Salerno, F.; Valsecchi, L.; Viviano, G.; Buzzi, F.; Agostinelli, C.; Formenti, R.; Marieri, A.; Tartari, G. Restoring lakes through external phosphorus load reduction: The case of Lake Pusiano (southern Alps). Inland Waters 2017, 7, 100-108. [CrossRef]

18. Walsby, A.E.; Schanz, F.; Schmid, M. The Burgundy-blood phenomenon: A model of buoyancy change explains autumnal waterblooms by Planktothrix rubescens in Lake Zürich. New Phytol. 2006, 169, 109-122. [CrossRef]

19. ISTISAN. Cyanobacteria: Guidelines for Managing Blooms in Bathing Waters; Rapporti ISTISAN: Roma, Italy, 2014. (In Itallian)

20. Buzzi, F. Phytoplankton assemblages in two sub-basins of Lake Como. J. Limnol. 2002, 61, 117-128. [CrossRef]

21. Salmaso, N. Factors affecting the seasonality and distribution of cyanobacteria and chlorophytes: A case study from the large lakes south of the Alps, with special reference to Lake Garda. Hydrobiologia 2000, 438, 43-63. [CrossRef]

22. Messineo, V.; Mattei, D.; Melchiorre, S.; Salvatore, G.; Bogialli, S.; Salzano, R.; Mazza, R.; Capelli, G.; Bruno, M. Microcystin diversity in a Planktothrix rubescens population from Lake Albano (Central Italy). Toxicon 2006, 48, 160-174. [CrossRef] 
23. Manganelli, M.; Scardala, S.; Stefanelli, M.; Vichi, S.; Mattei, D.; Bogialli, S.; Ceccarelli, P.; Corradetti, E.; Petrucci, I.; Gemma, S.; et al. Health risk evaluation associated to Planktothrix rubescens: An integrated approach to design tailored monitoring programs for human exposure to cyanotoxins. Water Res. 2010, 44, 1297-1306. [CrossRef] [PubMed]

24. Naselli-Flores, L.; Barone, R.; Chorus, I.; Kurmayer, R. Toxic cyanobacterial blooms in reservoirs under a semiarid Mediterranean climate: The magnification of a problem. Environ. Toxicol. 2007, 22, 399-404. [CrossRef]

25. Bogialli, S.; Nigro di Gregorio, F.; Lucentini, L.; Ferretti, E.; Ottaviani, M.; Ungaro, N.; Abis, P.P.; Cannarozzi de Grazia, M. Management of a toxic cyanobacterium bloom (Planktothrix rubescens) affecting an Italian drinking water basin: A case study. Environ. Sci. Technol. 2013, 47, 574-583. [CrossRef] [PubMed]

26. Schwarzenberger, A.; Kurmayer, R.; Martin-Creuzburg, D. Toward disentangling the multiple nutritional constraints imposed by Planktothrix: The significance of harmful secondary metabolites and sterol limitation. Front. Microbiol. 2020, 11, 586120. [CrossRef]

27. Walsby, A.E.; Dubinsky, Z.; Kromkamp, J.C.; Lehmann, C.; Schanz, F. The effects of diel changes in photosynthetic coefficients and depth of Planktothrix rubescens on the daily integral of photosynthesis in Lake Zürich. Aquat. Sci. 2001, 63, 326-349. [CrossRef]

28. Vaughan, I.P.; Davis, P.A.; Walsby, A.E. Changes in the photosynthetic coefficients $\alpha$ and Pm of Planktothrix rubescens grown on light-dark cycles. Aquat. Sci. 2001, 63, 350-362. [CrossRef]

29. Carraro, E.; Guyennon, N.; Hamilton, D.; Valsecchi, L.; Manfredi, E.; Viviano, G.; Salerno, F.; Tartari, G.; Copetti, D. Coupling highresolution measurements to a three-dimensional lake model to sssess the spatial and temporal dynamics of the cyanobacterium Planktothrix rubescens in a medium-sized lake. Hydrobiologia 2012, 698, 77-95. [CrossRef]

30. Boscaini, A.; Brescancin, F.; Cerasino, L.; Fedrigotti, C.; Fano, E.A.; Salmaso, N. Vertical and horizontal distribution of the microcystin producer Planktothrix rubescens (Cyanobacteria) in a small perialpine reservoir. Adv. Oceanogr. Limnol. 2017, 208-221. [CrossRef]

31. Legnani, E.; Copetti, D.; Oggioni, A.; Tartari, G.; Palumbo, M.T.; Morabito, G. Planktothrix rubescens' seasonal dynamics and vertical distribution in Lake Pusiano (North Italy). J. Limnol. 2005, 64, 61-73. [CrossRef]

32. Briand, J.-F.; Jacquet, S.; Flinois, C.; Avois-Jacquet, C.; Maisonnette, C.; Leberre, B.; Humbert, J.-F. Variations in the microcystin production of Planktothrix rubescens (Cyanobacteria) Assessed from a four-year survey of Lac Du Bourget (France) and from laboratory experiments. Microb. Ecol. 2005, 50, 418-428. [CrossRef]

33. Huang, W.; Xing, W.; Li, D.; Liu, Y. Microcystin-RR induced apoptosis in tobacco BY-2 suspension cells is mediated by reactive oxygen species and mitochondrial permeability transition pore status. Toxicol. In Vitro 2008, 22, 328-337. [CrossRef]

34. Salmaso, N.; Copetti, D.; Cerasino, L.; Shams, S.; Capelli, C.; Boscaini, A.; Valsecchi, L.; Pozzoni, F.; Guzzella, L. Variability of microcystin cell quota in metapopulations of Planktothrix rubescens: Causes and implications for water management. Toxicon 2014, 90, 82-96. [CrossRef]

35. Haruštiaková, D.; Welker, M. Chemotype diversity in Planktothrix rubescens (Cyanobacteria) populations is correlated to lake depth. Environ. Microbiol. Rep. 2017, 9, 158-168. [CrossRef]

36. Briand, E.; Gugger, M.; François, J.-C.; Bernard, C.; Humbert, J.-F.; Quiblier, C. Temporal variations in the dynamics of potentially microcystin-producing strains in a bloom-forming Planktothrix agardhii (Cyanobacterium) population. Appl. Environ. Microbiol. 2008, 74, 3839-3848. [CrossRef]

37. Assennato, G.; Blonda, M.; Cudillo, B.; Gifuni, S.; Rosaria Petruzzelli, M.; Maria Pastorelli, A.; Ungaro, N. Cyanobacteria bloom in the Occhito artificial lake (southern Italy): Relationship between Planktothrix rubescens density and microcystin concentration. Fresenius Environ. Bull. 2010, 19, 1795-1801.

38. IOCCG. Observation of Harmful Algal Blooms with Ocean Colour Radiometry; International Ocean Colour Coordinating Group (IOCCG): Dartmouth, NS, Canada, 2021.

39. Sellman, B. Coastal zone color scanner (CZCS) and related technologies. In Satellite Remote Sensing for Resources Development; Szekielda, K.-H., Ed.; Springer: Dordrecht, The Netherlands, 1986; pp. 93-97, ISBN 978-94-011-7364-3.

40. Kutser, T.; Metsamaa, L.; Strömbeck, N.; Vahtmäe, E. Monitoring cyanobacterial blooms by satellite remote sensing. Estuar. Coast. Shelf Sci. 2006, 67, 303-312. [CrossRef]

41. Mishra, S.; Stumpf, R.P.; Schaeffer, B.A.; Werdell, P.J.; Loftin, K.A.; Meredith, A. Measurement of cyanobacterial bloom magnitude using satellite remote sensing. Sci. Rep. 2019, 9, 18310. [CrossRef] [PubMed]

42. Kutser, T. Quantitative detection of chlorophyll in cyanobacterial blooms by satellite remote sensing. Limnol. Oceanogr. 2004, 49, 2179-2189. [CrossRef]

43. Hunter, P.D.; Tyler, A.N.; Willby, N.J.; Gilvear, D.J. The spatial dynamics of vertical migration by Microcystis aeruginosa in a eutrophic shallow lake: A case study using high spatial resolution time-series airborne remote sensing. Limnol. Oceanogr. 2008, 53, 2391-2406. [CrossRef]

44. Bresciani, M.; Giardino, C.; Lauceri, R.; Matta, E.; Cazzaniga, I.; Pinardi, M.; Lami, A.; Austoni, M.; Viaggiu, E.; Congestri, R.; et al. Earth observation for monitoring and mapping of cyanobacteria blooms. Case studies on five Italian lakes. J. Limnol. 2017, 76, 127-139. [CrossRef]

45. Papageorgiou, G.C. Govindjee Advances in Photosynthesis and Respiration. In Chlorophyll a Fluorescence. A Signature of Photosynthesis; Springer: Dordrecht, The Netherlands, 2004; ISBN 978-1-4020-3218-9.

46. Simis, S.G.H.; Kauko, H.M. In Vivo Mass-specific absorption spectra of phycobilipigments through selective bleaching. Limnol. Oceanogr. Methods 2012, 10, 214-226. [CrossRef] 
47. Beutler, M.; Wiltshire, K.H.; Reineke, C.; Hansen, U.P. Algorithms and practical fluorescence models of the photosynthetic apparatus of red cyanobacteria and Cryptophyta designed for the fluorescence detection of red cyanobacteria and Cryptophytes. Aquat. Microb. Ecol. 2004, 35, 115-129. [CrossRef]

48. Bresciani, M.; Giardino, C.; Bartoli, M.; Tavernini, S.; Bolpagni, R.; Nizzoli, D. Recognizing harmful algal bloom based on remote sensing reflectance band ratio. J. Appl. Remote Sens. 2011, 5, 053556. [CrossRef]

49. Maltese, A.; Capodici, F.; Ciraolo, G.; Corbari, C.; Granata, A.; La Loggia, G. Planktothrix rubescens in freshwater reservoirs: The sentinel-2 potentiality for mapping phycocyanin concentration. Remote Sensing for Agriculture, Ecosystems, and Hydrology XIV. In Proceedings of the SPIE Volume 8531, 85311X, Edinburg, UK, 24-26 September 2012.

50. Gitelson, A. The peak near $700 \mathrm{Nm}$ on radiance spectra of algae and water: Relationships of its magnitude and position with chlorophyll concentration. Int. J. Remote Sens. 1992, 13, 3367-3373. [CrossRef]

51. Gitelson, A.A.; Dall'Olmo, G.; Moses, W.; Rundquist, D.C.; Barrow, T.; Fisher, T.R.; Gurlin, D.; Holz, J. A simple semi-analytical model for remote estimation of chlorophyll-a in turbid waters: Validation. Remote Sens. Environ. 2008, 112, 3582-3593. [CrossRef]

52. Bernard, S.; Pitcher, G.; Evers-King, H.; Robertson, L.; Matthews, M.; Rabagliati, A.; Balt, C. Ocean colour remote sensing of harmful algal blooms in the benguela system. In Remote Sensing of the African Seas; Barale, V., Gade, M., Eds.; Springer: Dordrecht, The Netherlands, 2014; pp. 185-203, ISBN 978-94-017-8007-0.

53. Bresciani, M.; Adamo, M.; De Carolis, G.; Matta, E.; Pasquariello, G.; Vaičiūtè, D.; Giardino, C. Monitoring blooms and surface accumulation of cyanobacteria in the Curonian Lagoon by combining MERIS and ASAR data. Remote Sens. Environ. 2014, 146, 124-135. [CrossRef]

54. Giardino, C.; Brando, V.E.; Gege, P.; Pinnel, N.; Hochberg, E.; Knaeps, E.; Reusen, I.; Doerffer, R.; Bresciani, M.; Braga, F.; et al. Imaging spectrometry of inland and coastal waters: State of the art, achievements and perspectives. Surv. Geophys. 2019, 40, 401-429. [CrossRef]

55. Assennato, G.; Blonda, M.; Cudillo, B.; Dalessandro, G.; Fascia, A.; Gifuni, S.; Napolitano, G.; Petruzzelli, R.; Ungaro, N. Cyanobacteria Recent Blooms in the Occhito Reservoir: Results from Three-Years Monitoring. In Proceedings of the ASABE-21st Century Watershed Technology Workshops: Improving Water Quality and the Environment, Bari, Puglia, Italy, 3-6 November 2014; pp. 486-493.

56. Leboulanger, C.; Dorigo, U.; Jacquet, S.; Le Berre, B.; Paolini, G.; Humbert, J.F. Application of a submersible spectrofluorometer for rapid monitoring of freshwater cyanobacterial blooms: A case study. Aquat. Microb. Ecol. 2002, 30, 83-89. [CrossRef]

57. Valderrama, J.C. Methods Used by the Hydrographic Department of the National Board of Fisheries; The Hydrographic Department of the National Board of Fisheries: Goteborg, Sweden, 1977.

58. Valderrama, J.C. The Simultaneous analysis of total nitrogen and total phosphorus in natural waters. Mar. Chem. 1981, 10, 109-122. [CrossRef]

59. APHA, AWWA, WEF. Standard Methods for the Examination of Water and Wastewater, 20th ed.; American Public Health Association, American Water Works Association, Water Environment Federation: Washington, DC, USA, 1998.

60. APHA, AWWA, WEF. Standard Methods for the Examination of Water and Wastewater. Method 4110 B. Determination of Anions by Ion Chromatography; American Public Health Association, American Water Works Association, Water Environment Federation: Washington, DC, USA, 2005.

61. Guzzella, L.; Ghislanzoni, L.; Pozzoni, F.; Cerasino, L.; Salmaso, N. Determinazione di tossine algali (microcistine e nodularina) nelle acque superficiali. Not. Dei Metodi Anal. IRSA 2010, 1, 17-31. (In Italian)

62. Rast, M.; Bezy, J.L.; Bruzzi, S. The ESA Medium Resolution Imaging Spectrometer MERIS a review of the instrument and its mission. Int. J. Remote Sens. 1999, 20, 1681-1702. [CrossRef]

63. Rahman, H.; Dedieu, G. SMAC: A Simplified method for the atmospheric correction of satellite measurements in the solar spectrum. Int. J. Remote Sens. 1994, 15, 123-143. [CrossRef]

64. Thode, H. Testing for normality. In Statistics: Books and Monographs; Marcel Dekker, Inc.: New York, USA, 2002; Volume 164, ISBN 0-8247-9613-6.

65. Copetti, D.; Guyennon, N.; Buzzi, F. Generation and dispersion of chemical and biological gradients in a large-deep multi-basin lake (Lake Como, North Italy): The joint effect of external drivers and internal wave motions. Sci. Total Environ. 2020, 749, 141587. [CrossRef] [PubMed]

66. Shannon, C.E.; Weaver, W. The Mathematical Theory of Communication; The University of Illinois Press: Urbana, IL, USA, 1964.

67. Uusitalo, L.; Fleming-Lehtinen, V.; Hällfors, H.; Jaanus, A.; Hällfors, S.; London, L. A Novel approach for estimating phytoplankton biodiversity. ICES J. Mar. Sci. 2013, 70, 408-417. [CrossRef]

68. Redfield, A. On the proportions of organic derivatives in sea water and their relation to the composition of plankton. In James Johnstone Memorial Volume; Daniel, R.J., Ed.; University Press of Liverpool: Liverpool, UK, 1934; pp. 177-192.

69. Morabito, G.; Oggioni, A.; Austoni, M. Resource Ratio and Human Impact: How Diatom assemblages in Lake Maggiore responded to oligotrophication and climatic variability. Hydrobiologia 2012, 698, 47-60. [CrossRef]

70. McDonald, R.I.; Douglas, I.; Revenga, C.; Hale, R.; Grimm, N.; Grönwall, J.; Fekete, B. Global urban growth and the geography of water availability, quality, and delivery. AMBIO 2011, 40, 437-446. [CrossRef]

71. Giordano, R.; Preziosi, E.; Romano, E. Integration of local and scientific knowledge to support drought impact monitoring: Some hints from an Italian case study. Nat. Hazards 2013, 69, 523-544. [CrossRef] 
72. Romano, E.; Guyennon, N.; Duro, A.; Giordano, R.; Petrangeli, A.B.; Portoghese, I.; Salerno, F. A Stakeholder oriented modelling framework for the early detection of shortage in water supply systems. Water 2018, 10, 762. [CrossRef]

73. WHO. Guidelines for Safe Recreational Water Environments. Volume 1 Coastal and Fresh Waters; World Health Organization: Geneva, Switzerland, 2003; ISBN 92-4-154580-1.

74. WHO. Guidelines for Drinking-Water Quality; World Health Organization: Geneva, Switzerland, 2011.

75. ISTISAN. Cyanobacteria in Water for Human Consumption: Guidelines for Risk Management. Volume 2; Lucentini, L., Ferretti, E., Di Gregorio, F.N., Eds.; Instituto Superiore di Santità: Rome, Italy, 2011; Volume 11/35. (In Italian)

76. Lee, S.; Jiang, X.; Manubolu, M.; Riedl, K.; Ludsin, S.A.; Martin, J.F.; Lee, J. Fresh produce and their soils accumulate cyanotoxins from irrigation water: Implications for public health and food security. Food Res. Int. 2017, 102, 234-245. [CrossRef]

77. McElhiney, J.; Lawton, L.A.; Leifert, C. Investigations into the inhibitory effects of microcystins on plant growth, and the toxicity of plant tissues following exposure. Toxicon 2001, 39, 1411-1420. [CrossRef]

78. Crush, J.R.; Briggs, L.R.; Sprosen, J.M.; Nichols, S.N. Effect of irrigation with lake water containing microcystins on microcystin content and growth of ryegrass, clover, rape, and lettuce. Environ. Toxicol. 2008, 23, 246-252. [CrossRef]

79. Saqrane, S.; Oudra, B. CyanoHAB occurrence and water irrigation cyanotoxin contamination: Ecological impacts and potential health risks. Toxins 2009, 1, 113-122. [CrossRef]

80. Roesler, C.; Uitz, J.; Claustre, H.; Boss, E.; Xing, X.; Organelli, E.; Briggs, N.; Bricaud, A.; Schmechtig, C.; Poteau, A.; et al. Recommendations for obtaining unbiased chlorophyll estimates from in situ chlorophyll fluorometers: A global analysis of WET Labs ECO sensors. Limnol. Oceanogr. Methods 2017, 15, 572-585. [CrossRef]

81. Soleimani, S.; Bozorg-Haddad, O.; Saadatpour, M.; Loáiciga, H.A. Optimal selective withdrawal rules using a coupled data mining model and genetic algorithm. J. Water Resour. Plan. Manag. 2016, 142, 04016064. [CrossRef]

82. Pahlevan, N.; Smith, B.; Schalles, J.; Binding, C.; Cao, Z.; Ma, R.; Alikas, K.; Kangro, K.; Gurlin, D.; Hà, N.; et al. Seamless retrievals of chlorophyll-a from Sentinel-2 (MSI) and Sentinel-3 (OLCI) in inland and coastal waters: A machine-learning approach. Remote Sens. Environ. 2020, 240, 111604. [CrossRef]

83. Matthews, M.W. A Current review of empirical procedures of remote sensing in inland and near-coastal transitional waters. Int. J. Remote Sens. 2011, 32, 6855-6899. [CrossRef]

84. Di Cicco, A.; Sammartino, M.; Marullo, S.; Santoleri, R. Regional empirical algorithms for an improved identification of phytoplankton functional types and size classes in the mediterranean sea using satellite data. Front. Mar. Sci. 2017, 4, 126. [CrossRef]

85. Das, P.K.; Seshasai, M.V.R. Multispectral sensor spectral resolution simulations for generation of hyperspectral vegetation indices from Hyperion data. Geocarto Int. 2015, 30, 686-700. [CrossRef]

86. Hestir, E.L.; Brando, V.E.; Bresciani, M.; Giardino, C.; Matta, E.; Villa, P.; Dekker, A.G. Measuring freshwater aquatic ecosystems: The need for a hyperspectral global mapping satellite mission. Remote Sens. Environ. 2015, 167, 181-195. [CrossRef]

87. Giardino, C.; Bresciani, M.; Braga, F.; Fabbretto, A.; Ghirardi, N.; Pepe, M.; Gianinetto, M.; Colombo, R.; Cogliati, S.; Ghebrehiwot, S.; et al. First evaluation of PRISMA level 1 data for water applications. Sensors 2020, 20, 4553. [CrossRef] [PubMed] 